\title{
Inhibition of 5-Lipoxygenase Product Synthesis by Natural Compounds of Plant Origin
}

\begin{abstract}
The biosynthesis of leukotrienes (LTs) is initiated by the transformation of free arachidonic acid to $\mathrm{LTA}_{4}$ by 5-lipoxygenase (5-LO). Subsequent enzymatic conversion of $\mathrm{LTA}_{4}$ yields $\mathrm{LTB}_{4}$ and the cysteinyl-LTs $\mathrm{C}_{4}, \mathrm{D}_{4}$ and $\mathrm{E}_{4}$. LTs have prominent functions in pathophysiology and are connected to numerous disorders including bronchial asthma, allergic rhinitis, inflammatory bowel and skin diseases, rheumatoid arthritis, cancer, osteoporosis and cardiovascular diseases. Pharmacological and genetic interruption of the 5LO pathway or blockade of LT receptors, serving as means for intervention with LTs, may be of therapeutic value for certain related disorders. Natural or plant-derived substances were among the first 5-LO inhibitors identified in the early 1980 s. To date, a huge number of diverse plant-derived compounds have been reported to interfere with 5-LO product synthesis. However, many investigations have addressed the efficacy of a given compound solely in cellular test systems and analysis of direct interference with 5-LO has been neglected. In the first part of this review, the biology and molecular pharmacology of the 5-LO pathway is summarized in order to understand its overall regulation and complexity as well as to comprehend the possible points of attack of compounds that eventually lead to inhibition of 5-LO product formation in intact cells. In the second part, natural compounds that interfere with 5-LO product formation are compiled and grouped into structural classes, and the underlying molecular mechanisms and structureactivity relationships are discussed.
\end{abstract}

\section{Key words}

5-Lipoxygenase $\cdot$ arachidonic acid $\cdot$ leukotrienes $\cdot$ leukocytes $\cdot$ inflammation · plants $\cdot$ natural compounds $\cdot$ inhibitors

\author{
Abbreviations \\ AA: $\quad$ arachidonic acid \\ CLP: $\quad$ coactosine-like potein \\ COX: cyclooxygenase \\ GPCR: G protein-coupled receptor \\ GPX: glutathione peroxidase \\ GSH: glutathione \\ FLAP: 5-lipoxygenase-activating protein \\ $\mathrm{H}(\mathrm{P}) \mathrm{ETE}$ : hydro(pero)xyeicosatetraenoic acid \\ iNOS: inducible nitric oxide synthase \\ LO: lipoxygenase \\ LOOH: lipid hydroperoxide \\ LT: leukotriene \\ MAPEG: membrane-associated proteins in eicosanoid and \\ glutathione metabolism \\ MAPK: mitogen-activated protein kinase \\ NDGA: nordihydroguaiaretic acid \\ $\mathrm{NF} \kappa \mathrm{B}: \quad$ nuclear factor $\kappa \mathrm{B}$ \\ PAF: $\quad$ platelet-activating factor \\ fMLP: $\quad N$-formyl-methionyl-leucyl-phenylalanine \\ PC: $\quad$ phosphatidylcholine \\ PL: $\quad$ phospholipase \\ PK: $\quad$ protein kinase \\ PMNL: polymorphonuclear leukocytes \\ PT: $\quad$ pentacylic triterpene \\ SAR: $\quad$ structure-activity relationships
} Phone: +49-7071-297-8793 · Fax: +49-7071-294-565 · E-mail: oliver.werz@uni-tuebingen.de

Received August 14, $2007 \cdot$ Revised September 3, $2007 \cdot$ Accepted September 8, 2007 


\section{The Leukotriene Synthetic Pathway}

Leukotrienes (LTs) are bioactive lipid mediators mainly produced and released from activated leukocytes [1]. The initial step in LT biosynthesis is the dioxygenation of free arachidonic acid (AA) by 5-lipopxygenase (5-LO), yielding 5(S)-hydroperoxyeicosatetraenoic acid (5-HPETE) that is further metabolized by 5-LO to the instable epoxide $\mathrm{LTA}_{4}$ (Fig. 1, for review see [2]). In neutrophils and monocytes, $\mathrm{LTA}_{4}$ can be converted to $\mathrm{LTB}_{4}$ by $\mathrm{LTA}_{4}$ hydrolase, whereas in mast cells and eosinophils, LTC $_{4}$ synthase or membrane-associated proteins in eicosanoid and glutathione metabolism (MAPEGs) can conjugate $\mathrm{LTA}_{4}$ with glutathione (GSH), yielding the cysteinyl-LT (Cys-LT) $\mathrm{C}_{4}$ that can be cleaved in the extracellular environment yielding $\mathrm{LTD}_{4}$ and then $\mathrm{LTE}_{4}$ (Fig.1). Alternatively, de novo synthesized $\mathrm{LTA}_{4}$ can be transferred to neighbouring cells that are unable to produce $\mathrm{LTA}_{4}$ itself but express $\mathrm{LTA}_{4}$ hydrolase or $\mathrm{LTC}_{4}$ synthase/MAPEGs (e. g., parenchymal cells or erythrocytes), allowing subsequent generation of $\mathrm{LTB}_{4}$ or $\mathrm{LTC}_{4}$, respectively [3]. Finally, when 5-LO and 12-LO or 15-LO act together, lipoxins (LXs) might be formed, that are bioactive trihydroxytetraene-containing lipid mediators functioning as stop signals for inflammatory responses [4].

\section{Biological Effects of Leukotrienes}

$\mathrm{LTB}_{4}$ is a potent chemoattractant for leukocytes causing adherence of phagocytes to vessel walls, neutrophil degranulation and release of superoxide anions, whereas cysLTs are potent bronchoconstrictors increasing vascular permeability and stimulating mucus secretion from airways [5]. These biological actions of LTs are mediated by specific $G$ protein-coupled receptors (GPCRs) on the surface of their target cells. The CysLTs bind to CysLT1 and CysLT2 receptors that signal via Gq proteins (for review, see [6]). For the CysLT1 receptor the agonist potency is $\mathrm{LTD}_{4}>>\mathrm{LTC}_{4}>\mathrm{LTE}_{4}$, whereas $\mathrm{LTC}_{4}$ and $\mathrm{LTD}_{4}$ exhibit similar poten-

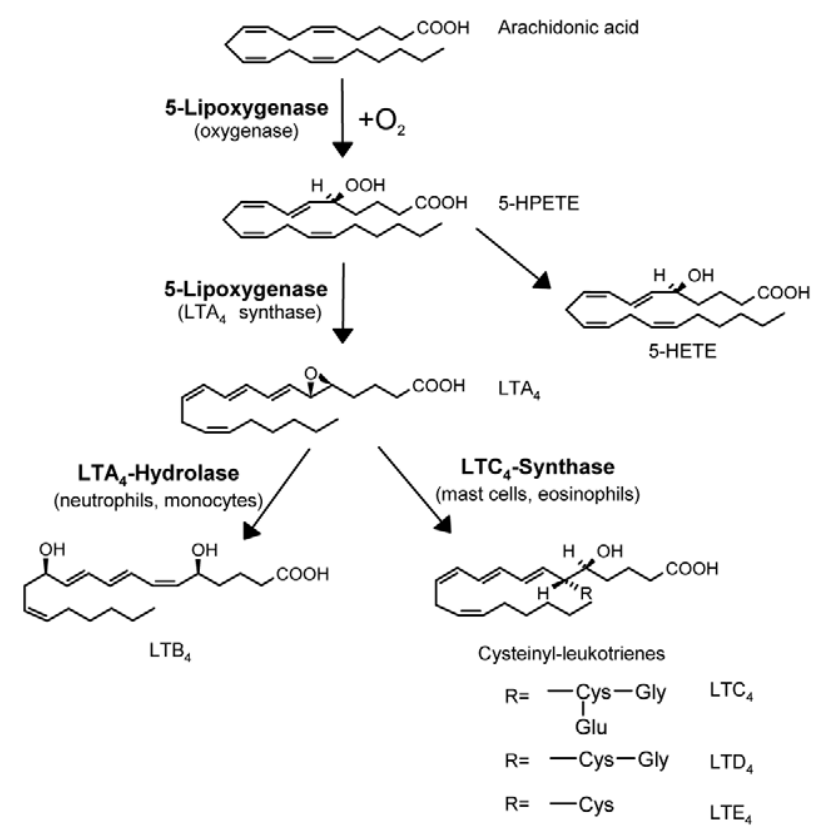

Fig. 1 Conversion of arachidonic acid by 5-lipoxygenase. LT = leukotriene; 5-H(P)ETE = 5-hydro(pero)xyeicosatetraenoic acid. cy at the CysLT2 receptor and $\mathrm{LTE}_{4}$ is a weak agonist [6]. The CysLT1 receptor is expressed in eosinophils, monocytes, macrophages, and bronchial smooth muscle cells whereas the CysLT2 receptor is expressed more ubiquitously. CysLT1 receptor mediates vascular leakage, bronchoconstriction, dendritic cell maturation and migration, but both receptors contribute to macrophage activation, smooth muscle proliferation and fibrosis. The CysLTR antagonists pranlukast, montelukast, zafirlukast, acting primarily on CysLT1, have been shown to be clinically efficacious in chronic asthma and have been successfully introduced into market [7]. The CysLT2 receptor is insensitive to these antagonists and the therapeutic potential of this receptor is unclear.

$\mathrm{LTB}_{4}$ binds BLT1 and BLT2 receptors, which show high homology (36-45\%), but quite distinct tissue distribution and distinct pharmacological properties (for review, see [6]). The BLT ${ }_{1}$ receptor is prominently expressed in leukocytes, possesses high affinity $\left(K_{\mathrm{d}}=0.39 \mathrm{nM}\right)$ and specificity for $\mathrm{LTB}_{4}$, and is coupled to $\mathrm{Gi}$ and Gq proteins [8]. BLT1 mediates typical effects of $\mathrm{LTB}_{4}$ including chemotaxis, formation of superoxide, release of lysosomal enzymes and leukocyte adhesion to endothelial cells. The BLT1 seems to be related to atherogenesis, bronchial asthma, glomerulonephritis, arthritis and chronic inflammatory bowel diseases (for review see [9]). The more widely expressed BLT2 binds $\mathrm{LTB}_{4}$ with a 20-fold lower affinity as BLT1 and the physiological and pathophysiological roles of the BLT2 are hardly understood.

Finally, a Gi-coupled GPCR specific for 5-oxo-ETE (formed by oxidation of 5-HETE) may exist in eosinophils, neutrophils and monocytes [10]. 5-Oxo-ETE is a chemoattractant for leukocytes and induces actin polymerization, $\mathrm{Ca}^{2+}$ mobilization, integrin expression and degranulation, stimulates the proliferation of prostate cancer cells [11], and may play a role in allergic asthma [12].

\section{5-LO and Diseases}

Initially, LTs have been identified as the chemical nature of the slow-reacting substance of anaphylaxis (SRSA) that induced a pronounced contraction of smooth muscles in a slow mode, and it soon became clear that LTs play important roles in inflammatory and allergic disorders. Therefore, bronchial asthma, allergic rhinitis, inflammatory skin diseases, rheumatoid arthritis, inflammatory bowel diseases, have long been accounted as 5-LOmediated or -associated (for review see [13]). Today, it is generally agreed that bronchial asthma is the major 5-LO-associated disease and, in fact, the available anti-LT therapy is approved for treatment of asthma only. On the other hand, LTs play a minor role in the pathophysiology of inflammatory bowel diseases and rheumatoid arthritis in humans. Similarly, the rather disappointing results of anti-LT drugs in psoriasis led to the conclusion that the 5-LO pathway is negligible in this disease.

Novel technologies in molecular biology and cell biology, mainly attributable to the elucidation of the receptors of LTs, genotyping approaches, and cumulating data from 5-LO knock-out mice led to deeper insights into the pathophysiology of 5-LO and its products in recent years. Accordingly, there are indications for novel disorders related to 5-LO products including osteoporosis [14], [15], cancer (i.e., prostate, pancreas and breast) [16], [17], [18], 
and cardiovascular diseases including atherosclerosis, heart attack and stroke [19], [20]. Clinical trials will reveal if anti-LT therapy is valuable for the treatment of these disorders.

\section{Expression and Structure of 5-LO}

Since LTs display strong biological effects it is not surprising that LT biosynthesis is tightly regulated. This regulation occurs on the transcriptional level (5-LO expression) as well as on the level of postranslational regulation and modulation by cofactors (5-LO enzyme activation) [21]. 5-LO is mainly expressed in mature leukocytes or dentritic cells, and the capability of cells to express 5LO is acquired during cell maturation [22]. Although the gene and promoter of 5-LO are well characterized and important insights into the molecular mechanism of 5-LO expression have been obtained during the past years [21], pharmacological inhibition of expression 5-LO is a minor strategy for intervention with LT formation. Nevertheless, when compounds are analyzed for inhibition of 5-LO using cellular test systems, an effect on the 5-LO protein level must be considered, in particular when long incubation periods (hours) are applied. Thus, plant extracts or plant-derived compounds able to induce apoptosis may reduce 5 -LO protein levels. In fact, functionally 5-LO protein can be cleaved by caspase-6 [23] that is activated in leukocytes in response to apoptosis-inducing agents.

Particular efforts have been made in order to establish pharmacological possibilities to block LT synthesis by interfering with 5LO enzyme activity. Along these lines, elucidation of the structure of the 5-LO protein and the understanding of the regulation of 5-LO activation and catalysis is of importance [24]. Thus far, the 3D structure of 5-LO has not been resolved, however, practicable computational models of 5-LO based on the structure of 15LO from rabbit have been created [23], [25]. These models indicate that 5 -LO consists of an $\mathrm{N}$-terminal C2-like $\beta$-barrel domain (AA 1 -121), with distinct functions and a C-terminal catalytic domain (AA 121 - 673) [26], [27].

The C-terminal catalytic domain contains a non-heme iron in the active site, coordinated by His-367, His-372, His-550, Asn-554 and the C-terminal Ile. This iron acts as an electron acceptor or donor during catalysis (for review see [28]). In the inactive form, the iron is in the ferrous state $\left(\mathrm{Fe}^{2+}\right)$ whereas catalytically active 5-LO requires conversion to the ferric $\left(\mathrm{Fe}^{3+}\right)$ iron, accomplished by oxidation by lipid hydroperoxides ( $\mathrm{LOOH}$ ). Note that most 5-LO inhibitors, synthetic ones as well as those from natural sources (e.g., polyphenols, coumarins, quinones) act at the catalytic domain by reducing or chelating the active-site iron, by reduction of activating $\mathrm{LOOH}$, or simply by scavenging electrons participating in the redox cycle of the iron [2], [24]. On the other hand, no data are available that demonstrate pharmacological inhibition of 5-LO by interfering with the C2-like domain.

The C2-like domain has a regulatory function, visualized by its ability to bind various lipids [phosphatidylcholine (PC), glycerides or lipid membranes] [29], [30], $\mathrm{Ca}^{2+}$ or $\mathrm{Mg}^{2+}$ ions [25], and coactosin-like protein (CLP) [31]. These interactions stimulate 5-LO catalysis in cell-free assays. In the cell, the C2-like domain functions as an anchor for association with the nuclear mem- brane, mediated by tryptophan residues (Trp-13, -75, and -102) in conjunction with $\mathrm{Ca}^{2+}[30]$, [32], and this process seemingly is essential for cellular 5-LO product synthesis. It is conceivable that (preferrably lipophilic) compounds may interrupt such 5LO membrane association (5-LO translocation inhibitors), thereby reducing 5-LO product synthesis in the cell. In addition, also the catalytic domain is subject for external regulation, in particular by phosphorylation of serine residues (see below). In view of the complexity of the 5-LO regulation, compounds that suppress cellular 5-LO product synthesis may not necessarily confer their inhibitory effect by direct interference with 5-LO catalysis. Instead, inhibition of proteins that act in conjunction with 5-LO (e.g., FLAP, CLP), prevention of stimulatory effects by certain regulatory co-factors, or blockade of signaling molecules that transduce external cell stimulation to 5-LO activation may be potential points of attack (see Table $\mathbf{1}$ ). Accordingly, the complex regulation of 5-LO activity in the cell often makes it difficult to distinguish if a certain compound that suppresses LT formation acts on 5-LO directly or alternatively interferes with concomitant or regulatory processes. The following chapters will focus on these regulatory elements and mechanisms that might be subject of interference with external compounds culminating in reduced 5-LO product synthesis.

\section{Analysis of Inhibition of 5-LO Product Synthesis: Possible Points of Attack for External Compounds}

\section{Test systems for evaluation of 5-LO inhibitors}

When reviewing the overwhelming amount of studies reporting about the identification of plant-derived compounds as "5-LO inhibitors" it became obvious that most studies applied cell-based test systems for assessing inhibition of 5-LO product synthesis, but only few studies have actually addressed a direct interaction of the test compound with 5-LO itself (by means of cell-free assays). Certainly, novel compounds that can be structurally and functionally grouped into the well-recognized classes of 5-LO inhibitors (see below) may be assumed to act directly on 5-LO. However, unless direct inhibition of 5-LO activity has not be demonstrated, the designation "5-LO inhibitor" is actually not justified. Moreover, the potency of a given compound may depend on the experimental settings and assay conditions that are different in each and every study.

Numerous different screening assays have been applied for the identification of inhibitors of 5-LO product synthesis that can be basically divided into (1) cellular test systems (e.g., whole blood, isolated primary leukocytes, 5-LO expressing cell lines) or (2) cell-free assays (e.g., leukocyte homogenates or cytosol, purified 5-LO enzyme). For conclusive analysis, both types of test systems should be applied. As discussed in the section below and summarized in Table $\mathbf{1}$, for cellular assays many possibilities aside from direct interference with 5-LO exist, eventually suppressing 5-LO product synthesis. On the other hand, the fact that a test compound inhibits 5-LO in cell-free assays does not unequivocally mean that this applies also for 5-LO in the cell.

For the evaluation of test compounds utilizing cellular test systems, the correct choice of the 5-LO metabolite(s) to be analyzed is essential. For example, many studies investigating plant-de- 
Table 1 Co-factors and mechanisms involved in 5-LO product formation and respective pharmacological interference by plant-derived compounds

\begin{tabular}{|c|c|c|c|}
\hline Factor/mechanism & $\begin{array}{l}\text { Proposed function leading to INDUCTION } \\
\text { of } 5 \text {-LO product synthesis }\end{array}$ & $\begin{array}{l}\text { Interference leading to INHIBITION } \\
\text { of } 5 \text {-LO product synthesis }\end{array}$ & (Plant-derived) compound \\
\hline cell viability/integrity & prerequisite for cellular response & $\begin{array}{l}\text { acute cytotoxicity causes loss of cellular } \\
\text { functionality }\end{array}$ & saponins [204] \\
\hline $\begin{array}{l}\text { agonist or respective } \\
\text { signaling molecules }\end{array}$ & $\begin{array}{l}\text { (receptor-coupled) cell stimulation and } \\
\text { signal transduction of 5-LO }\end{array}$ & $\begin{array}{l}\text { interruption of agonist-induced signal } \\
\text { (e.g. receptor blockade) and signal trans- } \\
\text { duction }\end{array}$ & gingkolide BN52021 [43] \\
\hline $\mathrm{CPLA}$ & liberation and supply of AA & $\begin{array}{l}\text { lack of substrate for } 5 \text {-LO product } \\
\text { formation }\end{array}$ & $\begin{array}{l}\text { manoalide [37], ochnaflavone } 24 \\
\text { [102] }\end{array}$ \\
\hline FLAP & $\begin{array}{l}\text { facilitation of AA transfer to } 5 \text {-LO at nuclear } \\
\text { membrane }\end{array}$ & failure of 5-LO to access AA as substrate & knipholone 54 [46] \\
\hline CLP & $\begin{array}{l}\text { binds and stimulates } 5 \text {-LO at the C2-like } \\
\text { domain }\end{array}$ & $\begin{array}{l}\text { interruption of stimulatory CLP - 5-LO } \\
\text { interaction }\end{array}$ & unknown \\
\hline $\begin{array}{l}\text { phosphorylation of 5-LO by } \\
\text { a) MK2 or ERKs } \\
\text { b) by PKA }\end{array}$ & $\begin{array}{l}\text { a) } 5 \text {-LO activation in the cell } \\
\text { b) inhibition of } 5 \text {-LO catalysis and nuclear } \\
\text { trafficking }\end{array}$ & $\begin{array}{l}\text { a) blockade of MK2/ERK pathway } \\
\text { b) elevation of } \mathrm{CAMP} / \text { stimulation of PKA }\end{array}$ & $\begin{array}{l}\text { a) quercetin } 11 \text { [58], [59] } \\
\text { b) ginkgetin } 25 \text { [40], [60] }\end{array}$ \\
\hline $\mathrm{Ca}^{2+}$ & $\begin{array}{l}\text { stimulates } 5 \text {-LO by decreasing } K_{\mathrm{m}} \text { for AA, } \\
\text { facilitates membrane binding, protects } \\
\text { against GPx }\end{array}$ & $\begin{array}{l}\text { suppression of } \mathrm{Ca}^{2+} \text { mobilization; } \mathrm{Ca}^{2+} \\
\text { chelation }\end{array}$ & deoxypodophyllotoxin 55 [50] \\
\hline PC or membranes & stimulation of 5-LO catalysis & $\begin{array}{l}\text { interruption of interaction with PC/ } \\
\text { membranes }\end{array}$ & unknown \\
\hline (diacyl)glycerides & $\begin{array}{l}\text { stimulation of 5-LO catalysis, protects } \\
\text { against GPx }\end{array}$ & $\begin{array}{l}\text { suppression of glyceride generation or } \\
\text { interaction }\end{array}$ & 1-butanol [205] \\
\hline ATP & binds and stimulates 5-LO catalysis & $\begin{array}{l}\text { ATP depletion or blockade of interaction } \\
\text { with } 5 \text {-LO }\end{array}$ & 2-deoxyglucose [206] \\
\hline redox tone & $\begin{array}{l}\text { LOOH facilitate to enter the redox cycle } \\
\text { of } 5 \text {-LO catalysis }\end{array}$ & $\begin{array}{l}\text { suppression of LOOH formation; reduction } \\
\text { of LOOH }\end{array}$ & vitamin C and E, carotenoids [207] \\
\hline nuclear membrane trafficking & enables 5-LO to access FLAP and AA & blockade of 5-LO translocation & genisteine [47] \\
\hline $\mathrm{LTA}_{4}$ hydrolase & conversion of $\mathrm{LTA}_{4}$ to $\mathrm{LTB}_{4}$ & selective suppression of $\mathrm{LTB}_{4}$ levels & bestatin [208] \\
\hline LTC4 synthase/MAPEGs & conversion of $\mathrm{LTA}_{4}$ to $\mathrm{LTC}_{4}$ & $\begin{array}{l}\text { selective suppression of } \mathrm{LTC}_{4}, \mathrm{D}_{4} \text {, and } \mathrm{E}_{4} \\
\text { levels }\end{array}$ & $\begin{array}{l}\text { thymoquinone } 77 \text { [63], } \\
\text { helenalin } 93 \text { [62] }\end{array}$ \\
\hline
\end{tabular}

rived compounds as " 5 -LO inhibitors" used ELISA techniques or HPLC methods in order to measure $\mathrm{LTB}_{4}$ or cysLTs (i.e., $\mathrm{LTC}_{4}, \mathrm{D}_{4}$ or $\mathrm{E}_{4}$ ). These techniques are indeed sensitive and (often) selective. However, if used as sole method, caution should be taken when interpreting the results. Thus, a given "active compound" could affect the enzymatic activities of $\mathrm{LTA}_{4}$ hydrolase or $\mathrm{LTC}_{4}$ synthases. Therefore, analysis of direct 5-LO derived products [i.e., 5-H(P)ETE and the trans- and epi-trans isomers of $\mathrm{LTB}_{4}$ ] is important in order to exclude such interrelations. In the subsequent section, the regulation of 5-LO enzyme and 5-LO product synthesis is described in order to understand possible points of attack that all may lead to suppression of 5-LO product synthesis.

\section{Release of arachidonic acid, redistribution/binding of 5-LO to the nuclear membrane, and the role of FLAP}

Based on the complex interplay of various proteins and the manifold mechanisms involved in cellular 5-LO product formation, a number of points of attack for a given compound are conceivable. First of all, acute cytotoxicity coupled to a loss of cell functionality by disruption of cell integrity must be taken into account as a factor leading to reduced LT synthesis, in particular when lipophilic extracts using organic solvents or high concentrations of detergent-like compounds [e.g., triterpenes (-sapononins), fatty acid derivatives] are applied.

Upon cell stimulation by an adequate agonist, 5-LO together with cytosolic phospholipase $\mathrm{A}_{2}\left(\mathrm{CPLA}_{2}\right)$ redistributes from a soluble cellular compartment to the nuclear membrane, where $\mathrm{CPLA}_{2}$ liberates AA from phospholipids, which is then transferred to 5LO by the membrane-bound 5-LO-activating protein (FLAP) [2], [33] (Fig. 2). Stimuli able to induce LT formation [e. g., $N$-formylmethionyl-leucyl-phenylalanine (fMLP), platelet-activating factor (PAF), $\mathrm{LTB}_{4}, \mathrm{C} 5 \mathrm{a}$, interleukin-8, phagocytic particles like zymosan, and ionophores] cause activation of 5-LO and CPLA 2 [2]. Thus, a given test compound may simply interfere with the stimulus used to evoke 5-LO product formation and/or with the distal signaling, or with AA release by inhibiting PLA $\mathrm{P}_{2}$ enzymes. Interestingly, 5-LO and $\mathrm{CPLA}_{2}$ share structural (C2 domain) and regulatory properties [activated by $\mathrm{Ca}^{2+}$ and by phosphorylation by members of the mitogen-activated protein kinase (MAPK) family] [31], [34]. Indeed, many studies revealed that natural compounds (e.g., flavonoids and other polyphenols) leading to suppression of LT formation also act as PLA $_{2}$ inhibitors preventing AA release [35], [36], [37], [38], [39], [40]. The anti-inflammatory sesterterpenoid manoalide, for instance, is an irreversible inhibitor of PLA $\mathrm{A}_{2}$ enzymes by covalently modifying lysine residues [41]. Initially, manoalide was proposed as a selective 5-LO inhibitor based on its ability to potently suppress the formation of LTs in human PMNL and in rat basophilic leukemia (RBL)-1 cells $\left(\mathrm{IC}_{50}=0.3 \mu \mathrm{M}\right)$ [42]. Later, more detailed investigations confirmed suppression of LT biosynthesis by manoalide, but the authors showed that the compound does not directly inhibit 5LO activity by analysis of the compound under cell-free assay conditions, suggesting that the inhibitory action is eventually 


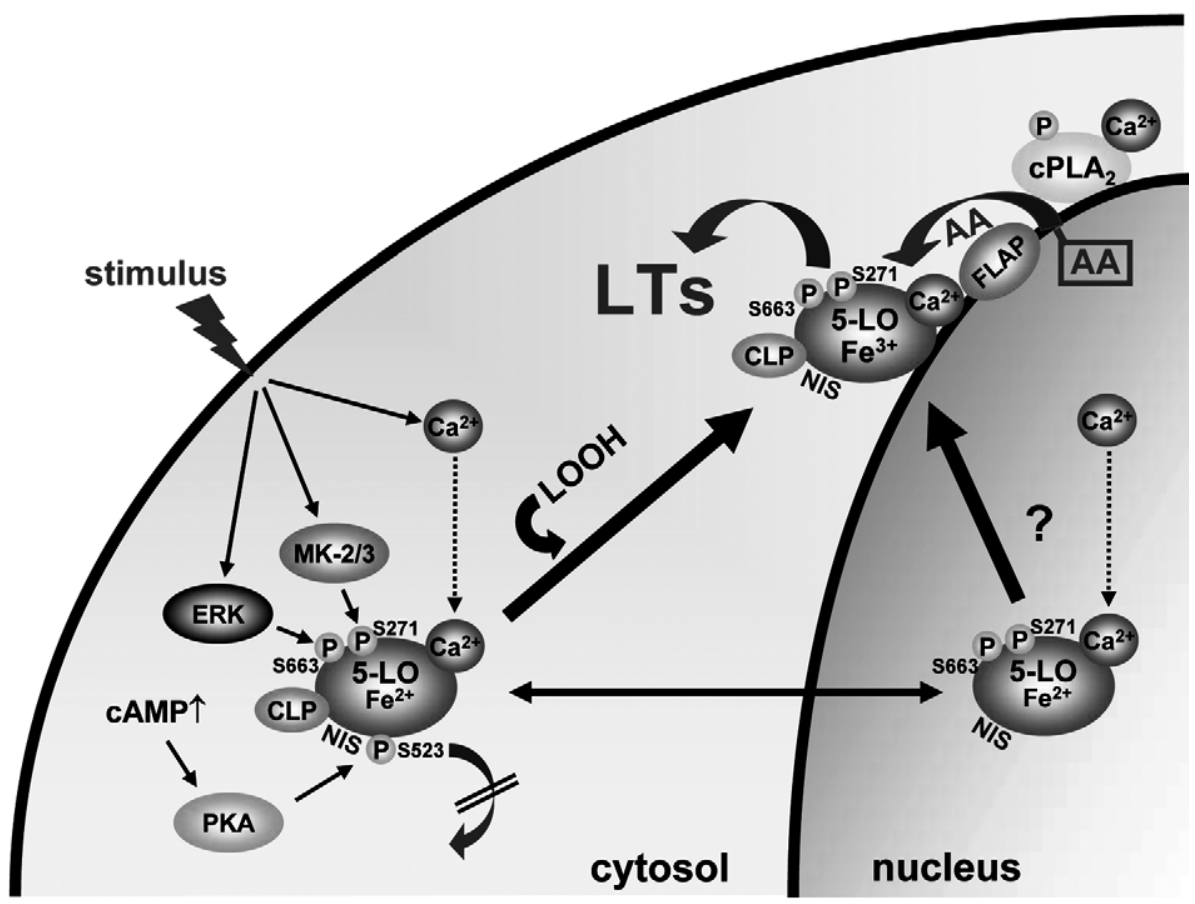

Fig. 2 Activation and signal transduction of 5-lipoxygenase in leukocytes. Upon cell stimulation, mobilisation of $\mathrm{Ca}^{2+}$ and activation of MK-2/3 and ERKs stimulate 5-LO in the cytosol. Moderate cell stimulation may lead to nuclear import of 5-LO, depending on the overall 5-LO phosphorylation state. Subsequent challenge may induce nuclear membrane association of intranuclear 5-LO. Robust stimulation causes direct translocatation of cytosolic 5-LO to the nuclear membrane where 5-LO binds in close proximity to the 5-lipoxygenase-activating protein (FLAP). In parallel, lipid hydroperoxides $(\mathrm{LOOH})$ confer the conversion of the active site iron from the ferrous to the ferric state. $\mathrm{AA}$ is released at the nuclear membrane (by $\mathrm{CPLA}_{2}$ ) and transferred via FLAP towards activated 5-LO for metabolism to $\mathrm{LTA}_{4}$ and 5-HPETE. Coactosin-like protein (CLP) is bound to 5-LO and stimulates catalysis. due to a blockade of $\mathrm{PLA}_{2}$ [37]. Also, (receptor) antagonists directed against the applied stimuli were found to suppress 5-LO product synthesis. For example, the gingkolide BN52021, a well-recognized PAF receptor antagonist inhibited LT formation in primed neutrophils, seemingly by antagonizing the actions of PAF [43].

The nuclear membrane-bound FLAP facilitates the access of AA to 5-LO, and in cells that lack FLAP or where FLAP is pharmacologically inhibited, transformation of endogenous AA by 5-LO is efficiently blocked [44]. It is clear that not only the supply of AA but also the access towards 5-LO is a prerequisite for LT biosynthesis [44], [45], and one important class of synthetic inhibitors of LT biosynthesis are so-called FLAP inhibitors (e.g., MK886 , Bay-X-1005). Among plant-derived compounds, the phenylanthraquinone knipholone 54 (Table 3 ), from the roots of Kniphofia foliosa, was suggested to suppress cellular 5-LO product synthesis by inhibition of FLAP [46].

Conversion of endogenously provided AA to LTA $_{4}$ occurs at the nuclear membrane, implying that 5-LO has to be present at this locale. In resting cells, 5-LO resides in the cytosol and/or in a nuclear soluble compartment, depending on the cell type [2]. For those cells with intranuclear 5-LO, an import process from the cytosol is needed, mediated by Arg- and Lys-rich nuclear import sequences (NIS), and putative NIS are present in the N-terminal part of 5-LO, and close to the C-terminus [33]. Regardless of the localization in resting cells, upon agonist challenge 5-LO translocates to the nuclear membrane, a process that requires elevation of $\left[\mathrm{Ca}^{2+}\right]_{i}$ and/or phosphorylations (Fig. 2). Conclusively compounds that interfere with cellular 5-LO trafficking will cause a suppression of LT formation. Among natural compounds, the isoflavone genisteine from soybean suppressed 5-LO product synthesis in ionophore-stimulated HL-60 cells due to inhibiting 5LO translocation [47].

\section{Activation pathways of 5-LO in the cell}

Signaling pathways and molecules that initialize the recruitment of resting 5-LO in the cell to become a catalytically active enzyme capable of converting AA essentially include $\mathrm{Ca}^{2+}$ ions and certain protein kinases (PKs). $\mathrm{Ca}^{2+}$ binds to the regulatory $\mathrm{C} 2$-like domain, mediates binding of 5-LO to PC-containing membranes or lipid vesicles, lowers the $K_{\mathrm{m}}$ value for AA as substrate, and decreases the requirement of 5-LO for activating $\mathrm{LOOH}$, which altogether potently enhances 5-LO catalysis in vitro [21], [24], [31]. In the cell, $\mathrm{Ca}^{2+}$ facilitates 5-LO association with the nuclear membrane and protects 5-LO activity against GPx activity [48]. Hence, it is reasonable to assume that natural compounds that chelate $\mathrm{Ca}^{2+}$ or interfere with $\mathrm{Ca}^{2+}$ mobilization (i.e., by blocking channels, or interaction with signaling molecules such as PLC, IP3 receptors) prevent activation of 5-LO without inhibiting the enzyme directly. For instance, the lignan deoxypodophyllotoxin $\mathbf{5 5}$ from Hernandia nymphaeifolia potently impairs the production of $\mathrm{LTC}_{4}\left(\mathrm{IC}_{50}=0.37 \mu \mathrm{M}\right)$ in intact cells [49], but a direct effect on 5-LO was not demonstrated. Of interest, it inhibited the increase in $\left[\mathrm{Ca}^{2+}\right]_{\mathrm{i}}$ induced by PAF, $\mathrm{LTB}_{4}$, and thapsigargin [50] that is required for activation of 5-LO. Also, the coumarin derivative osthol $\mathbf{7 0}$ from Angelica pubescens exhibits $\mathrm{Ca}^{2+}$-channel blocking properties [51] and inhibits 5-LO in intact cells [52], [53], but direct inhibition of 5-LO has not been shown.

Recently, 5-LO kinases, namely the p38 MAPK-regulated MAPKAPK-2/3, the ERK1/2, CaMKII and PKA [54], [55], [56], [57] that phosphorylate 5 -LO in vitro were identified. Phosphorylations by MAPKAPKs and ERKs at Ser-271 and Ser-663, respectively, activate 5 -LO in the cell, whereas phosphorylation by PKA at Ser523 suppresses 5-LO translocation and 5-LO catalysis. Interestingly, most stimuli that activate 5-LO in the cell are able to raise $\left[\mathrm{Ca}^{2+}\right]_{\mathrm{i}}$ and/or lead to activation of ERK1/2 and MAPKAPK-2 [24]. Since certain natural compounds possess the ability to block PK activities, those interfering with ERK1/2 and/or MAPKAPK-2 or 
the respective upstream signaling pathways could block cellular 5-LO product formation by such routes as well. In fact, the flavonoid quercetin $\mathbf{1 1}$ that suppresses 5-LO product synthesis also blocks the ERK1/2 and p38 MAPK pathway [58], [59], and plantderived tyrosine kinase inhibitors such as genistein reduced 5LO activation in HL60 cells [47]. Moreover, agents that cause elevation of cAMP (e.g., ginkgetin $\mathbf{2 5}$ from Ginkgo biloba, a potent inhibitor of cellular 5-LO product synthesis [40], [60]) and thus stimulation of PKA may suppress 5-LO activity and translocation by such mechanisms.

In order to enter the catalytic cycle, 5-LO requires conversion of the ferrous iron to the active ferric state, conferred by certain LOOHs. Accordingly, the capacity of the cell to form LT is strongly linked to the peroxide tone. Agents that promote lipid peroxidation upregulate 5-LO product synthesis, whereas on the other hand, withdrawal of peroxides suppresses 5-LO product formation (for review, see [2]). It should be observed that many plantderived natural compounds (i.e., flavonoids, coumarins, chinones, polyphenols) have reducing properties which may cause reduction of 5-LO product formation also by decreasing the peroxide tone in addition to acting on 5-LO directly.

As outlined above, in addition to these regulatory mechanisms acting on or upstream of 5-LO product synthesis, the subsequent transformation of $\mathrm{LTA}_{4}$ to $\mathrm{LTB}_{4}$ by $\mathrm{LTA}_{4}$ hydrolase or to $\mathrm{LTC}_{4}$ by LTC $_{4}$ synthase/MAPEGs provide additional points of attack. This should be taken into account, in particular when only $\mathrm{LTB}_{4}$ or cysLTs are measured as 5-LO derived products. Well-recognized inhibitors of $\mathrm{LTA}_{4}$ hydrolase are bestatin, captopril, and kelatorphan that reduce formation of $\mathrm{LTB}_{4}$ without affecting 5-LO [61]. The sesquiterpene lactone helenalin 93, present in species of the Asteraceae family, and thymoquinone $\mathbf{7 7}$ from Nigella sativa directly inhibit $\mathrm{LTC}_{4}$ synthase besides inhibition of 5-LO [62], [63].

\section{Molecular Pharmacology of 5-Lipoxygenase Inhibitors}

Based on the pathophysiological implications of 5-LO products and the potential benefit of an anti-LT therapy in a variety of diseases, great efforts have been made within the past 25 years in order to develop selective and potent pharmacological agents that intervene with LTs. Basically, two different strategies have been pursued to reach this aim: (I) inhibition of the biosynthesis of LTs and (II) inhibition of the action of LTs.

Synthetic derivatives of LTs or prostaglandins were first described as inhibitors of LT biosynthesis [64], [65]. To achieve reduction of LT formation, reasonable targets include $\mathrm{PLA}_{2}$ enzymes, 5-LO, FLAP, LTA 4 hydrolase and $\mathrm{LTC}_{4}$ synthase/MAPEGs, with 5-LO being the preferred target. Although experiments in ${ }_{C P L A}$-deficient mice support the concept that inhibition of PLA $A_{2}$ enzymes prevents the formation of basically all eicosanoids [66], clinical studies using glucocorticoids that suppress $\mathrm{CPLA}_{2}$ enzymes proved to be ineffective in reducing the levels of LTs [5].

Most of the compounds that interfere with LT synthesis are direct 5-LO inhibitors, that advantageously block the formation of both $\mathrm{LTB}_{4}$ and cysLTs as well as the synthesis of 5-H(P)ETE. These direct 5-LO inhibitors are classified according to their molecular mode of action as (1) redox-active 5-LO inhibitors, (2) iron-ligand inhibitors, (3) non-redox-type 5-LO inhibitors, and finally (4) compounds that act on 5-LO by so far unrecognized mechanisms (for review see [2]).

Redox-active 5-LO inhibitors comprise lipophilic reducing agents, and among those there are many prominent plant-derived classes like flavonoids, coumarins, quinones, coumarins, lignans and other polyphenols. Also the first synthetic 5-LO inhibitors belong to the class of redox-type 5-LO inhibitors, represented by AA-861 1, L-656,224 2, phenidone, or BW755C [67], [68] (Fig. 3). These drugs act by keeping the active site iron in the ferrous state, thereby uncoupling the catalytic cycle of the enzyme and are highly efficient inhibitors of 5-LO product formation in vitro and partially also in vivo. However, most of them lack suitable oral bioavailability, possess only poor selectivity for 5-LO and thus, exert severe side-effects (e.g., methemoglobin formation) due to interference with other biological redox systems or by the production of reactive radical species [69]. These detrimental features hampered the substances to enter the market.<smiles>CC1=C(C)C(=O)C(CCCC#CCCC#CCO)=C(C)C1=O</smiles><smiles>CC(=O)N(O)C/C=C/c1cccc(Oc2ccccc2)c1</smiles>

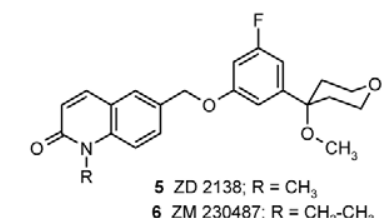<smiles>CCCc1cc(Cl)c2c(O)c3cc(Cc4ccc(Cl)cc4)oc3c([14CH3])c2c1</smiles>

9 licofelone
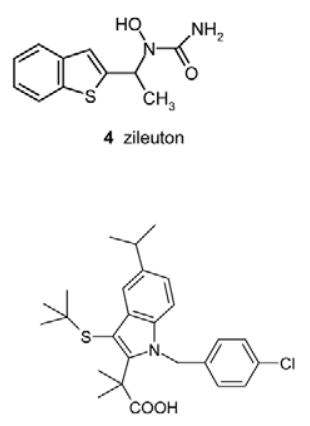

10 MK-886
Fig. 3 Chemical structures of different types of synthetic inhibitors of 5-LO product synthesis. AA-861 1 and L-656,224 2 are redox-type 5-LO inhibitors, BWA4C 3 and zileuton 4 are iron-ligand-type 5-LO inhibitors, ZD 2138 5, ZM 230487 6, L-697,198 7 and L-739,010 8 are non-redox-type 5-LO inhibitors, MK-886 10 is a FLAP inhibitor, and licofelone 9 is a dual inhibitor of COX and 5-LO product synthesis. 
Iron ligand inhibitors chelate the active site iron via a hydroxamic acid or an $\mathrm{N}$-hydroxyurea moiety and also exert weak reducing properties. BWA4C 3, a hydroxamic acid and zileuton 4, a hydrolytic stable $N$-hydroxyurea derivative belong to this class of potent and orally-active 5-LO inhibitors [70], [71]. Zileuton (Zyflo ${ }^{\circledR}, \mathrm{IC}_{50}=0.5-1 \mu \mathrm{M}$ in stimulated leukocytes) has been available in the USA for the treatment of asthma, but was discontinued in June, 2003 and is currently being re-evaluated for clinical efficacy. Zileuton improved acute and chronic airway functions, associated with a decreased need for beta-agonists or glucocorticoids [72]. However, the therapeutic potential in allergic rhinitis, rheumatoid arthritis, and inflammatory bowel disease was low [73].

The non-redox-type 5-LO inhibitors compete with AA or LOOH for binding to 5-LO without redox properties and encompass structurally diverse molecules. It is still unclear if the bindingsite of these compounds is in fact the AA substrate-binding cleft in the active site. Thus, experimental data from molecular and biochemical studies suggest an allosteric mode of action [74]. Nonetheless, representatives out of this class such as the orally active compounds ZD 21385 or its ethyl analogue ZM 2304876 or L-739.010 8 are highly potent and selective for 5-LO in cellular assays [24]. We found that elevated peroxide levels and/or phosphorylation of 5-LO by MAPKAPK-2 and/or ERKs strongly impaired the potency of non-redox-type 5-LO inhibitors in activated PMNL [74], [75], [76].

Recent developments in the field of anti-inflammatory drugs yielded compounds that act not solely on 5-LO, but also on other relevant targets including COX enzymes, the PAF or the $\mathrm{H} 1$ receptor (so-called dual inhibitors) [77]. A prominent representative is licofelone 9 (ML-3000, currently undergoing phase III trials) that potently inhibits 5-LO and COX product formation in the submicromolar range [78]. In fact, many plant-derived compounds have been described to suppress the activities of both 5LO and COX enzymes (see below). Incorporation of an $\mathrm{N}$-hydroxyurea functionality onto well-characterized PAF receptor antagonists consisting of 2,5-diaryltetrahydrofurans (CMI-392) resulted in a potent dual function compound (5-LO and PAF) [79] which may provide therapeutic advantages over agents with only single activity [77]. Similarly, hybrid molecules containing $\mathrm{N}$-hydroxyureas or $\mathrm{N}$-hydroxycarbamates (5-LO pharmacophore) connected to benzhydryl piperazines $\left(\mathrm{H}_{1}\right.$ receptor antagonistic moiety) are currently developed for the treatment of asthma [80], [81].

An indirect pharmacological strategy to reduce the formation of LTs is the inhibition of FLAP. Cells expressing 5-LO but lacking FLAP produced no LTs, although 5-LO was active in the corresponding homogenates [82]. No LT synthesis is detectable in FLAP-deficient macrophages from knock-out mice [83]. The indole MK-886 10 was the first synthetic FLAP inhibitor that potently inhibits 5-LO product formation in intact isolated leukocytes $\left(\mathrm{IC}_{50}=2.5 \mathrm{nM}\right)$ [84]. However, in whole blood MK-886 10 is much less efficient $\left(\mathrm{IC}_{50}, 1.1 \mu \mathrm{M}\right)$, and $\mathrm{LTB}_{4}$ biosynthesis ex vivo in whole blood was only partially blocked [85]. In addition to indole structures, quinolines and hybrid structures of indoles and quinolines were found to bind FLAP and to inhibit LT biosynthesis in intact cells. Obviously, these FLAP inhibitors are po- tent blockers of LT synthesis in isolated PMNL, whereas in whole blood assays the drugs are 50- to 200-fold less active [86], [87], possibly due to high plasma protein binding of the drugs and/or competition with AA and other fatty acids for binding to FLAP [88].

\section{Inhibitors of 5-LO Product Synthesis from Plant Origin}

Starting from the early 1980 s until today, several hundred reports have described plant extracts and/or specific ingredients thereof capable of suppressing the biosynthesis of 5-LO products. In most of these studies, plant-derived compounds were tested for their ability to block LT synthesis in isolated cells from rat, mice or human sources. In 1981, Bokoch and Reed published the polyphenol nordihydroguaiaretic acid 41 (NDGA) from the Mexican dessert plant Larrea divaricata as the first plant-derived 5-LO inhibitor [65]. Later, Koshihara et al. reported about natural compounds isolated from the Chinese plant Artemisia rubris, which were caffeic acid 36, eupatilin and 4-demethyleupatilin that inhibited 5-LO activity in a cell free-assay as well as the formation of $\mathrm{LTC}_{4}$ and $\mathrm{D}_{4}$ in ionophore-stimulated mastocytoma cells [89]. Like NDGA 41, caffeic acid $\mathbf{3 6}$ is a lipophilic phenolic compound, and eupatilin and 4-demethyleupatilin are flavones, and all of them possess reducing properties, thus, acting as antioxidants. In parallel, esculetin $\mathbf{6 5}$, an ortho-dihydroxycoumarin derivative present in many plants, was identified as a 5-LO inhibitor [90]. Note that these different "5-LO active" compounds mentioned (and many more, see below) have a cathechol partial structure in common, and it is assumed that the combined ironchelating and antioxidant feature of this moiety is eventually responsible for uncoupling of the 5-LO catalytic cycle. Since the plant kingdom is a rich source for various polyphenols, flavonoids and coumarins, subsequent investigations addressed various representatives with phenolic or coumarin structure from different plants [91], [92], [93]. A second class of plant-derived 5-LO inhibitors constitutes compounds lacking reducing properties that may mimic fatty (arachidonic) acid structures including polyacetylenes, and triterpenes and thus, inhibit 5-LO activity by binding and/or competing at the substrate-binding site or at a hypothetical fatty acid-binding cleft of 5-LO.

In the following section it is attempted to compile and group plant-derived compounds that have been reported to interfere with 5-LO product synthesis primarily according to structural aspects but also with respect to their mode of action. The respective test systems, differentiated into cell-based (intact cells) or cell-free assays have been considered and specified. Moreover, focus is placed on the effects of compounds on 5-LO, whereas effects on related enzymes including PLA $2,12 / 15-\mathrm{LO}$, COX and NOS (that are in fact quite frequent) as well as in vivo efficacy in animal models or human studies have been mainly neglected. This list is far away from being complete and only compounds are considered that efficiently ( IC $_{50}<50 \mu \mathrm{M}$ ) block 5-LO product formation. It is worthwhile to mention that most of these compounds have been evaluated in only one type of assay, preferably a cellular test system, which makes it exceedingly difficult to deduce concrete structure-activity relationships (SARs) due to multiple possible targets. As discussed above, from results obtained from only a cell-based assay, it is critical to designate an active compound as a "direct 5-LO inhibitor". 


\section{Flavonoids and other polyphenols}

Polyphenols, basically grouped into flavonoids, phenolic acids (mainly caffeic acid derivatives), stilbenes and lignans are the most abundant antioxidants in consumed food together with other dietary reducing agents (e.g., carotenoids, vitamin $\mathrm{C}$ and E). They protect cells and tissues against oxidative stress and against associated pathologies such as cancers, cardiovascular disease and inflammation [94]. Epidemiological studies indicate that populations consuming specific polyphenol-rich food have a lower incidence of chronic inflammatory disorders and there is evidence that the health benefits associated with fruits, vegetables and red wine are linked to the antioxidant properties of polyphenols [95]. Nevertheless, most beneficial effects of polyphenols have been obtained from in vitro studies, and the bioavailability and bioefficacy is affected by various metabolic transformations during digestion and absorption in vivo. Potential molecular mechanisms of polyphenols underlying the antiinflammatory activities include differential interference with AA cascade-dependent ( $\left.\mathrm{PLA}_{2}, \mathrm{COX}, \mathrm{LOs}\right)$ and AA cascade-independent enzymes or receptors [e.g., $\mathrm{NOS}, \mathrm{NF} \kappa \mathrm{B}$, peroxisome proliferator-activated receptors (PPARs) and NAG-1], depending on the overall structure of each individual polyphenol [94], [96]. Seemingly, a combination of iron-chelating and iron-reducing properties (frequently as catechol structure) mediates inhibition of 5-LO activity.

Flavonoids are widely distributed in the plant kingdom and more than 4000 derivatives have been identified [97]. Besides anticancer, antiviral, antimicrobial, immunmodulatory and antithrombotic activities, the anti-inflammatory properties, observed in vitro and in vivo, are most recognized. Thus, flavonoids have been shown to inhibit acute or chronic inflammation in various animal models such as rat Freund's adjuvant arthritis [98], [99] and carrageenan-induced mouse paw edema, when given orally [99], [100]. In particular, however, flavonoids showed beneficial effects in AA-induced ear edema, when applied topically (for review see [97]). The reduction of reactive oxygen species and the suppression of eicosanoid biosynthesis due to interference with PLA ${ }_{2}$, COX and LO enzymes may be the major underlying molecular mechanisms. However, flavonoids can also act on the transcriptional level, interfering with the expression of iNOS, COX-2 and cytokines.

Together with other polyphenols (see below), flavonoids constitute the most prominent class of plant-derived inhibitors of 5-LO product synthesis. Since many (potent) flavonoids have been analyzed for inhibition of 5-LO product synthesis only in intact cells, it is not always clear if reduced formation of 5-LO products is caused by direct inhibition of 5-LO or by inhibition of PLA $\mathrm{P}_{2}$ enzymes (reduced AA supply). In fact, certain biflavonoids like ginkgetin 25 [101] and ochnaflavone 24 [102] or papyriflavonol $\mathbf{2 0}$ [103] and quercetin $\mathbf{1 1}$ [104] that all suppress 5-LO product synthesis, efficiently inhibit PLA $\mathrm{P}_{2}$ enzymes.

As shown in Table 2, 5-O-demethylnobiletin 16, cirsiliol 17, luteolin $\mathbf{1 9}$, papyriflavonol 20, ginkgetin 25 , and rhamnetin 14 potently suppress 5 -LO product formation in intact cells with $\mathrm{IC}_{50}$ values below $1 \mu \mathrm{M}$. In cell-free assays, quercetin 11, 5-O-demethylnobiletin 16, cirsiliol 17, artonin $E \mathbf{2 2}$, sophoraflavanone $G \mathbf{3 0}$, and kenunsanone A $\mathbf{3 1}$ are potent 5-LO inhibitors ( $\left.\mathrm{IC}_{50}<1 \mu \mathrm{M}\right)$ with sophoraflavanone G 30, a prenylated flavanol from Sophora flavescens, being most efficient $\left(\mathrm{IC}_{50}=0.09-0.25 \mu \mathrm{M}\right)$ [105]. Solely for quercetin 11, 5-O-demethylnobiletin 16, cirsiliol 17 and papyriflavonol 20 was the efficacy in both cellular and cell-free assays determined (Table $\mathbf{2}$ ), where the effectiveness appeared generally somewhat higher under cell-free conditions. An exception is papyriflavonol $\mathbf{2 0}$ which is more potent in intact cells, presumably due to higher lipophilicity (two prenyl residues) and thus, intracellular accumulation and/or additional intracellular effects. SARs imply that compounds with vicinal phenolic hydroxy groups, that is hydroxylation in positions $3^{\prime}$ and $4^{\prime}$ of ring $C$, seem superior over unsubstituted (i.e., baicalein 18), mono-hydroxylated (xanthomicrol 15) or tri-hydroxylated (myricetin 12) derivatives ( $\mathrm{IC}_{50}=7-29 \mu \mathrm{M}$, Table 2 ). Nevertheless, an ortho-dihydroxy structure is not essential since sophoraflavanone $G \mathbf{3 0}$ and kenusanone A $\mathbf{3 1}$ lacking this moiety are most potent. It is interesting that also flavonoids where the hydroxy groups are replaced by methoxy functions are highly effective. For example, the polymethoxyflavone 5-O-demethylnobiletin $\mathbf{1 6}$ from Sideritis tragoriganum carries only one free $\mathrm{OH}$ group but is one of the most potent representatives $\left(\mathrm{IC}_{50}=0.25\right.$ and $\left.0.35 \mu \mathrm{M}\right)$ [106]. On the other hand no clear SARs are obvious with respect to variations of the nature and number of substitutents at ring A. Also, the C2,3-double bond as well as the $\mathrm{C}-3-\mathrm{OH}$ in ring $\mathrm{B}$ seem not absolutely required, since kenusanone A $\mathbf{3 1}$ lacking the double bond [105], and epicatechin 32, a flavanol [107], are significantly active. Regarding the $\mathrm{C}-3-\mathrm{OH}$ in ring $\mathrm{B}$, luteolin $\mathbf{1 9}$ (lacking this moiety) is even more potent than its direct counterpart quercetin 11, a flavon-3-ol derivative [108]. Of interest, the prenylated flavonoids including payriflavonol 20, morusin 21, artonin E 22, sanggenon D 26, sophoraflavanone $G \mathbf{3 0}$ and kenusanone $A \mathbf{3 1}$ are highly efficient direct 5-LO inhibitors with $\mathrm{IC}_{50}$ values 0.09 to $7 \mu \mathrm{M}$ in cellfree assays [105]. Unfortunately, among those, only for papyriflavonol 20 has the efficacy in intact cells been demonstrated [103]. Although for inhibition of cellular 5-LO, the flavonoid aglycones are generally superior over the corresponding glycosides, the myricetin 3-O- $\beta$-D-glucuronide $\mathbf{1 3}$ is more efficient than the corresponding aglycone myricetin $\mathbf{1 2}$ under comparable assay conditions [99], [109], probably related to more effective cellular uptake of the glycoside by specific transporters. Finally, one should observe that different studies evaluating essentially the same compound may come up with completely different efficacies, as in the case of quercetin $\mathbf{1 1}\left(\mathrm{IC}_{50}=0.3\right.$ or $25 \mu \mathrm{M}$ [110], [111]) or morusin $21\left(\mathrm{IC}_{50}=2.9\right.$ or $>100 \mu \mathrm{M}$ [105], [112]) analyzed in cellfree assays, again implying that the results obtained in each and every study strongly depend on the respective experimental settings of the test system.

Since conventional flavonoids show only weak efficacy after oral administration, presumably due to poor bioavailability (low absorption) and/or rapid metabolism and elimination, the more lipophilic prenylated derivatives may possess the advantage of facilitated membrane (and skin) penetration in addition to their higher potency as 5-LO inhibitors, suggesting a potential for topical treatment of inflammatory skin diseases [103], [105], [113]. Nevertheless, oral intake of flavonoid-rich nutrition (i. e., chocolate) led to significant decreases in the plasma concentrations of cys-LTs in human subjects [114] supporting the beneficial effects of daily dietary intake of flavonoids. 
Table 2 Flavonoids that inhibit 5-LO product synthesis (n.d. = not determined)

\begin{tabular}{|c|c|c|c|c|c|c|}
\hline No. & Compound & Structure & $I C_{50}$, intact & $I C_{50}$, cell-free & Plant & Ref. \\
\hline 11 & quercetin & & $3.2 \mu \mathrm{M}$ & $0.3 \mu \mathrm{M}, 25 \mu \mathrm{M}$ & $\begin{array}{l}\text { Lonicera japonica, } \\
\text { ubiquitous }\end{array}$ & $\begin{array}{l}{[209],} \\
{[110],} \\
{[111]}\end{array}$ \\
\hline 12 & myricetin & & $13 \mu \mathrm{M}$ & n.d. & ubiquitous & [109] \\
\hline 13 & $\begin{array}{l}\text { myricetin-3-O- } \beta \text {-D- } \\
\text { glucuronide }\end{array}$ & & $\begin{array}{l}0.1 \mu \mathrm{M} \text { (rat), } \\
2.2 \mu \mathrm{M} \text { (human) }\end{array}$ & n.d. & Epilobium angustifolium & [99] \\
\hline 14 & rhamnetin & & $0.7 \mu \mathrm{M}$ & n.d. & Guiera senegalensis & {$[210]$} \\
\hline 15 & xanthomicrol & & $29.2 \mu \mathrm{M}$ & n.d. & Stachys chrysantha & [211] \\
\hline 16 & 5-O-demethylnobiletin & & $0.35 \mu \mathrm{M}$ & $\approx 0.25 \mu \mathrm{M}$ & Sideritis tragoriganum & {$[106]$} \\
\hline 17 & cirsiliol & & $0.4 \mu \mathrm{M}$ & $0.1 \mu \mathrm{M}$ & Salvia officinalis & [91] \\
\hline 18 & baicalein & & $\begin{array}{l}7.13 \mu \mathrm{M} \\
9.5 \mu \mathrm{M}\end{array}$ & n.d. & Scutellaria baicalensis & $\begin{array}{l}{[212],} \\
{[98]}\end{array}$ \\
\hline 19 & luteolin & & $0.1 \mu \mathrm{M}$ & n.d & ubiquitous & {$[108]$} \\
\hline 20 & papyriflavonol & & $0.64 \mu \mathrm{M}$ & $7 \mu \mathrm{M}$ & Broussnetia papyriferra & $\begin{array}{l}{[105],} \\
{[103]}\end{array}$ \\
\hline 21 & morusin & & n.d. & $\begin{array}{l}2.9 \mu \mathrm{M} \\
>100 \mu \mathrm{M}\end{array}$ & Morus alba & $\begin{array}{l}{[112],} \\
{[105]}\end{array}$ \\
\hline 22 & artonin $\mathrm{E}$ & & n.d. & $0.36 \mu \mathrm{M}$ & Artocarpus communis & [112] \\
\hline
\end{tabular}


Table 2 cont.

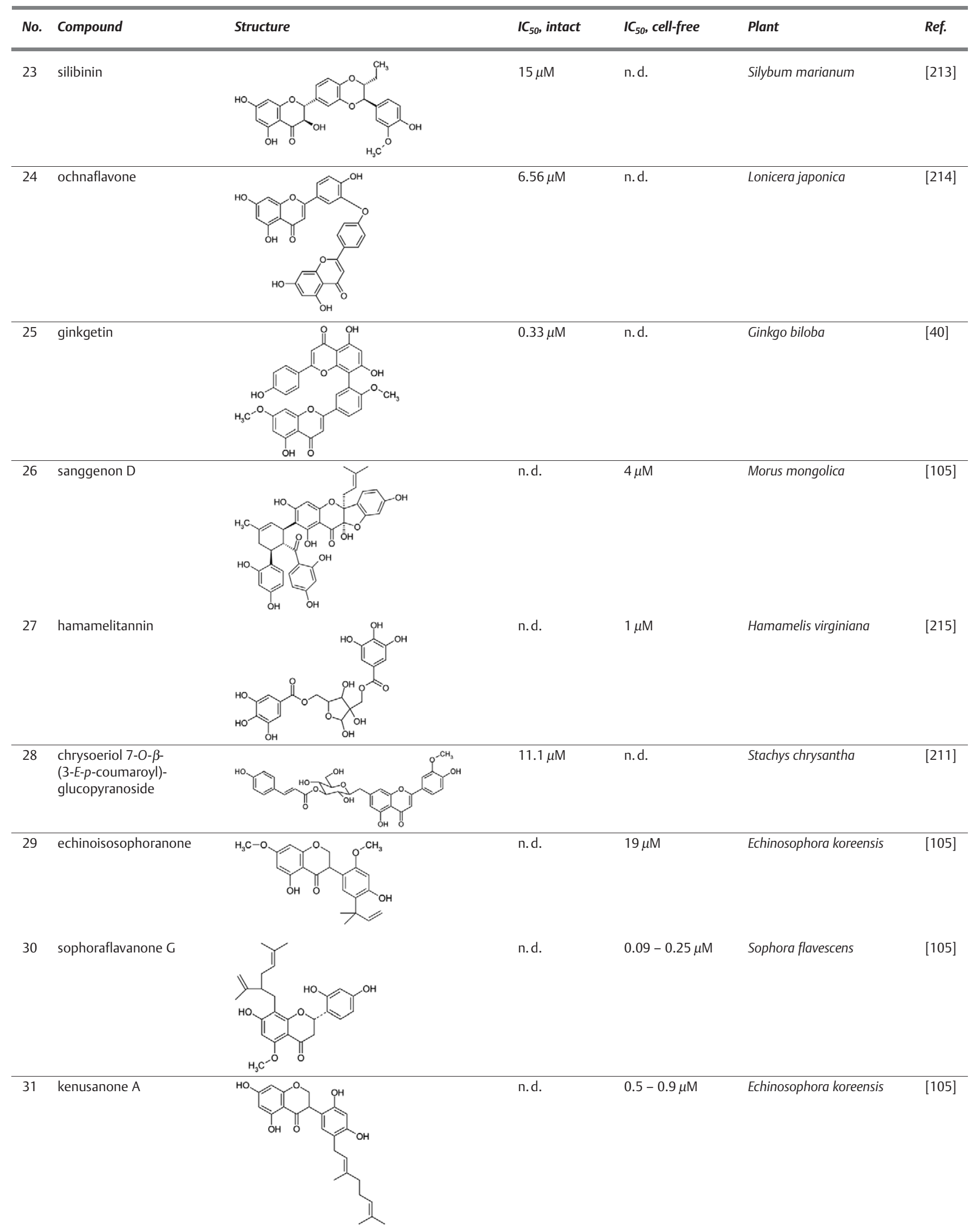


Table 2 cont.

No. Compound 32 epicatechin

In addition to flavonoids, other groups of polyphenols constitute rich sources of inhibitors of 5-LO product synthesis. These compounds greatly vary in their structure and consequently in their efficacy. Mechanistically, polyphenols (like flavonoids) may act as antioxidants thereby keeping the active site iron of 5-LO in the inactive ferrous state, and the para-hydroxy group might mediate the iron-chelating properties. In Table 3, a number of structurally different polyphenols are compiled. Just as for the flavonoids, most of the 5-LO inhibition experiments were exclusively performed using cell-based assays, whereas only few studies have addressed inhibition of cell-free 5-LO and even less data are available from evaluations in both assay systems.

In intact cells, gingerols 53 [115], [116], 6-hydroxy-2-(2-hydroxy4-methoxyphenyl)benzofuran 51 [117], 2-[(2'E)-3',7'-dimethyl2',6'-octadienyl]-4-methoxy-6-methylphenol 40 [118], hyperforin 48 [119], NDGA 41 [65], 3,4,2',4'-tetrahydroxy-2-geranyldihydrochalcone 60 [120], deoxypodophyllotoxin 55 [49], and the related lignan derivative diphyllin acetylapioside 56 [121] are highly efficient inhibitors of 5-LO with $\mathrm{IC}_{50}$ values of 0.004 to $3 \mu \mathrm{M}$. From these data, clear SARs are not immediately apparent, although it seems that increased lipophilicity (due to extended alkyl or alkylene chains) and increasing numbers of phenolic hydroxy groups govern the potency. This can be visualized by comparison of hydroxytyrosol 34, composed of a catechol structure and a hydroxyethyl residue $\left(\mathrm{IC}_{50}=10-26 \mu \mathrm{M}\right)$ [122], [123], and urushiol 43, possessing an extended alkyl chain $\left(\mathrm{IC}_{50}=2 \mu \mathrm{M}\right)$ [124].

For some compounds, the potency for 5-LO inhibition correlates to the ability to scavenge reactive oxygen species or to unspecifically suppress lipid peroxidation [109], but on the other hand polyphenols without free phenolic $\mathrm{OH}$ groups (i.e., deoxypodophyllotoxin 55) or derivatives lacking strong antioxidant properties (hyperforin 48, myrtucommulone 49) are highly efficient 5 LO inhibitors [119], [125], [126]. Also, many polyphenols that efficiently block 5-LO fail to inhibit the related 12- and 15-LOs that also exert a sensitive iron redox cycling. It is obvious that most of the active polyphenols resemble fatty acid-like structures, either possessing a (vinylogue) carboxylic acid moiety (e.g., caffeic acid $\mathbf{3 6}$, hyperforin $\mathbf{4 8}$, myrtucommulone $\mathbf{4 9}$, lobaric acid $\mathbf{5 7}$, and rosmarinic acid 42) or an acidic phenol core (e.g., NDGA 41, curcu- min 52). For caffeic acid phenethyl ester $\left(\mathrm{IC}_{50}\right.$ for purified 5 -LO < $10 \mu \mathrm{M}$ ) exhibiting antioxidant properties, an uncompetitive binding to the 5-LO-substrate complex, but not to the free 5-LO enzyme, was demonstrated [127]. A recent study [128] applied surface plasmon resonance biosensor technology to investigate the binding features of typical 5-LO inhibitors, among them NDGA 41, caffeic acid 36 and the 6,7-dihydroxylated coumarin esculetin 65 (see below) that are all assumed to act as antioxidants at the active site of 5-LO. The equilibrium dissociation constants $\left(K_{\mathrm{D}}\right)$ values showed a good correlation to the reported $\mathrm{IC}_{50}$ values implying that in addition to the antioxidant capacity the binding of these compounds parallels 5-LO interference [128]. Collectively, multiple structural and chemical features determine the 5-LO inhibitory action of polyphenols and definite SARs are hard to be deduced.

Remarkably potent polyphenols that inhibit 5-LO in cellular as well as in cell-free assays in the submicromolar range are the benzofuran derivatives medicarpin $\mathbf{5 0}$ and 6-hydroxy-2-(2-hydroxy-4-methoxyphenyl)benzofuran $\mathbf{5 1}$ from the Chinese plant Dalbergia odorifera (Jiangxiang) ( $\mathrm{IC}_{50}=50-500 \mathrm{nM}$ ) [117], 3,4,2',4'-tetrahydroxy-2-geranyldihydrochalcone $\mathbf{6 0}$ from Artocarpus communis $\left(\mathrm{IC}_{50}=0.05-1 \mu \mathrm{M}\right)$ [120] and the acylphloroglucinols hyperforin 48 ( $\mathrm{IC}_{50}=0.09-1.2 \mu \mathrm{M}$ ) from St. John's wort (Hypericum perforatum L.) [119], and myrtucommulone 49 (IC $_{50}=1.8-5 \mu \mathrm{M}$ ) from myrtle (Myrtus communis L.) [126]. These compounds may be regarded as potent and direct 5-LO inhibitors. Similarly, the well-recognized curcumin 52 from Curcuma longa L. [39], [129] and the structurally related gingerols 53 from Zingiber officnialis Roscoe [115], [116] proved to inhibit 5-LO in cell-based and cell-free assays with $\mathrm{IC}_{50}<$ $1 \mu \mathrm{M}$. Interestingly, compared to the prenylated hyperforin 48 , the structurally related polyphenols such as erychristagallin $\mathbf{4 6}$ [130], or kuraridin 47 [105] possessing lipophilic prenyl residues (that seemingly enhance the potency of flavonoids) are significantly less effective with $\mathrm{IC}_{50}$ values $>20 \mu \mathrm{M}$. Among the most recognized bioactive polyphenols, also the stilbene resveratrol 37 has been reported to inhibit 5-LO product synthesis in PMNL with $\mathrm{IC}_{50}$ values in the low micromolar range [93], [131]. Taken together, polyphenols (including flavonoids) are a rich source of plant-derived inhibitors of 5-LO product synthesis. Given their inhibitory action also on $\mathrm{PLA}_{2}$ and related diooxygenases within the AA cascade (such as 12-LO and COX- 
Table 3 Polyphenols that inhibit 5-LO product synthesis

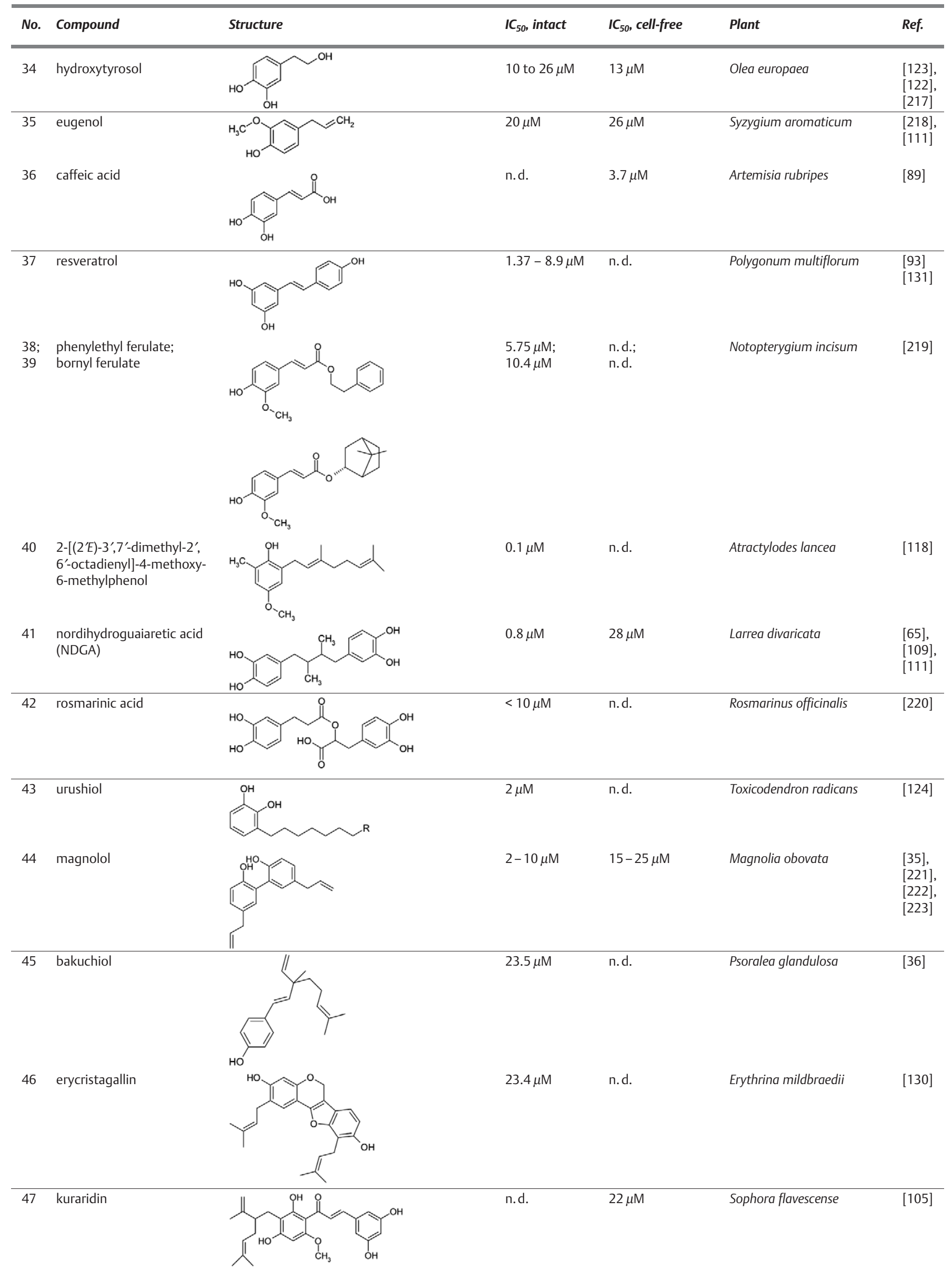


Table 3 cont.

\begin{tabular}{|c|c|c|c|c|c|c|}
\hline No. & Compound & Structure & $I C_{50}$, intact & $I C_{50}$, cell-free & Plant & Ref. \\
\hline 48 & hyperforin & & $1.2 \mu \mathrm{M}$ & $0.09 \mu \mathrm{M}$ & Hypericum perforatum & [119] \\
\hline 49 & myrtucommulone & & $1.8 \mu \mathrm{M}$ & $5 \mu \mathrm{M}$ & Myrtus communis & [126] \\
\hline 51 & $\begin{array}{l}\text { 6-hydroxy-2-(2-hydroxy-4- } \\
\text { methoxyphenyl)-benzofuran }\end{array}$ & & $0.05 \mu \mathrm{M}$ & $0.08 \mu \mathrm{M}$ & Dalbergia odorifera & {$[117]$} \\
\hline 52 & curcumin & & $2.7 \mu \mathrm{M}$ & $0.7-30 \mu \mathrm{M}$ & Curcuma longa & $\begin{array}{l}{[39],} \\
{[129],} \\
{[111]}\end{array}$ \\
\hline 53 & gingerols & & $0.004-3 \mu \mathrm{M}$ & n.d. & Zingiber officinalis & $\begin{array}{l}{[116],} \\
{[115]}\end{array}$ \\
\hline 56 & diphyllin acetylapioside & & $0.5 \mu \mathrm{M}$ & $\approx 10 \mu \mathrm{M}$ & Haplophyllum hispanicum & [121] \\
\hline 57 & lobaric acid & & $5.5 \mu \mathrm{M}$ & n.d. & Stereocaulon alpinum & [224] \\
\hline 58 & carnosol & & $2 \mu \mathrm{M}$ & n.d. & Rosmarinus offcinalis & [109] \\
\hline
\end{tabular}




\begin{tabular}{|c|c|c|c|c|c|c|}
\hline No. & Compound & Structure & $I C_{50}$, intact & $I C_{50}$, cell-free & Plant & Ref. \\
\hline 59 & $\begin{array}{l}\text { monocaffeoylprenylhydro- } \\
\text { quinone glucoside }\end{array}$ & & $33 \mu \mathrm{M}$ & n.d. & Phagnalon rupestre & {$[225]$} \\
\hline $\begin{array}{l}62 \\
63 \\
64\end{array}$ & $\begin{array}{l}\text { stemofuran G; } \\
\text { stemanthrenes A } \\
\text { and D }\end{array}$ & & $\begin{array}{l}3.7 \mu \mathrm{M} \\
8.5 \mu \mathrm{M} \\
4.8 \mu \mathrm{M}\end{array}$ & n.d. & Stemona species & {$[226]$} \\
\hline
\end{tabular}

$1 / 2$ ), intervention with the biosynthesis of eicosanoids may be one important mode of action underlying the anti-inflammatory properties of these compounds.

\section{Coumarins}

The almost two thousand coumarins identified from plants, fungi and bacteria comprise a class of phenolic compounds made of fused benzene and $\alpha$-pyrone rings (see Table 4 ). The biological effects of coumarin (1,2-benzopyrone) itself and 7-hydroxycoumarin (umbeliferrone) have been well studied [132]. The manifold possible substitutions and conjugations at the basic coumarin structure offer a great variety of distinct derivatives that occur naturally, and these modifications eventually determine the pharmacological and biochemical properties of the respective coumarin [133], [134]. Although coumarin itself and 7-hydroxycoumarin do not inhibit 5-LO, the 6,7-dihydroxycoumarin esculetin 65 has long been recognized as a 5-LO inhibitor [90]. Coumarin was suggested to act as prodrug, since metabolism in man leads to hydroxylation at C-7, and obviously, 5-LO-active coumarins possess a 7-hydroxy moiety. In general, coumarins with an ortho-dihydroxy moiety such as esculetin 65 [90], [135], 4-methylesculetin, daphnetin $\mathbf{6 6}$ and fraxetin $\mathbf{6 7}$ [135] suppress 5-LO product formation with $\mathrm{IC}_{50}$ values of 1.46 to $10 \mu \mathrm{M}$ (compare Table 4 ), more or less accompanied by efficient inhibition of lipid peroxidation and scavenging of superoxide and aqueous alkylperoxyl radicals [135], [136]. It was suggested that, like polyphenols, the high potency of dihydroxylated coumarins is related to the combined effect of the compounds to chelate the active-site iron and to interrupt the iron redox cycle by donating electrons [134], [136]. Similarly, the dihydroxylated coumestan derivative wedelolactone $\mathbf{7 2}$ from Ecliptica alba potently inhibits
5-LO in porcine leukocytes ( $\mathrm{IC}_{50}=2.5 \mu \mathrm{M}$ ), seemingly by an oxygen radical scavenger mechanism [137]. However, the 6-(3-carboxybut-2-enyl)-7-hydroxycoumarin $\mathbf{6 8}$ from Peucedanum ostruthium, characterized by only one $\mathrm{OH}$ moiety, a prenyl residue and a carboxylic group, is the most potent coumarin derivative $\left(\mathrm{IC}_{50}=0.25 \mu \mathrm{M}\right.$ in a cell-based assay) [138]. This compound showed marked effectiveness in carrageenan-induced rat paw edema after oral administration $\left(E_{50}=0.03 \mathrm{mg} / \mathrm{kg}\right)$ [138]. Also other monohydroxylated (osthenol 69 and psoralidin 73 [52], [53], [105]) or O-alkyl derivatives (osthol 70 and imperatorin 71, that lack free phenolic hydroxy groups at all [52], [53], [139]) inhibit 5-LO product synthesis, albeit less efficiently. The latter compounds contain prenyl residues that apparently govern interference with 5 -LO product formation. As for polyphenols, substantial data are available for the efficacy of coumarin derivatives on 5-LO in intact cell assays, but only sparsely have results been reported about their direct inhibitory action on 5-LO (Table 4). In contrast to many flavonoids and other polyphenols, coumarins are relatively selective for 5-LO and hardly inhibit other enzymes within the AA cascade such as 12/15-LOs, PLA 2 and COX enzymes.

\section{Quinones}

Compounds possessing an 1,4-benzoquinone moiety exemplified by the synthetic substance 2,3,5-trimethyl-6-(12-hydroxy-5,10dodecadiynyl)-1,4-benzoquinone (AA-861; 1), have long been reported as potent 5-LO inhibitors [67]. In the cell, the quinone moiety is reduced to hydroquinone which is able to reduce the active site iron in 5-LO, suggesting that the reducing character confers 5-LO enzyme inhibition [140]. However, as in the case of flavonoids, polyphenols and coumarins the potency of quinones 
Table 4 Coumarins that inhibit 5-LO product synthesis

\begin{tabular}{|c|c|c|c|c|c|c|}
\hline No. & Compound & Structure & $I C_{50}$, intact & $I C_{50}$, cell-free & Plant & Ref. \\
\hline 65 & esculetin & & $1.46 \mu \mathrm{M}, 4 \mu \mathrm{M}$ & n.d. & ubiquitous & $\begin{array}{l}{[135],} \\
{[90]}\end{array}$ \\
\hline 68 & $\begin{array}{l}\text { 6-(3-carboxybut-2-enyl)- } \\
\text { 7-hydroxycoumarin }\end{array}$ & & $0.25 \mu \mathrm{M}$ & n.d. & Peucedanum ostruthium & [138] \\
\hline 70 & osthol & & $36.2 \mu \mathrm{M}$ & n.d & Atractylodes lancea & $\begin{array}{l}{[52],} \\
{[53]}\end{array}$ \\
\hline 71 & imperatorin & & $<15 \mu \mathrm{M}$ & n.d. & Cachrys trifida & [139] \\
\hline 72 & wedelolactone & & $2.5 \mu \mathrm{M}$ & n.d. & Eclipta alba & [137] \\
\hline 73 & psoralidin & & n.d. & $3.6-8.8 \mu \mathrm{M}$ & Psoralea corylifolia & [105] \\
\hline
\end{tabular}

does not solely depend on the reducing properties but also parallels their lipophilicity. For example, inhibition of 5-LO by AA-861 1 was found to be competitive with regard to AA [67]. Also, a mechanistic analysis of the interaction of $\alpha$-tocopherol (vitamin E, also a 1,4-benzoquinone derivative) with purified 5-LO showed that the potent 5 - $\mathrm{LO}$ inhibition $\left(\mathrm{IC}_{50}=5 \mu \mathrm{M}\right.$ ) is unrelated to the antioxidant function, but instead is accounted by a selective and tight binding of $\alpha$-tocopherol to a single 5-LO peptide [141].

In 1993, Fukuyama first reported about naturally occurring 5-LO inhibitors with a quinone structure derived from the rhizome of Ardisia japonica (Blume). This [142] and subsequent studies [143], [144], [145], [146] identified ardisianone A 76, ardisiaquinones A 74, B 75a, D 75b, E 75c, and F 75d, as well as maesanin 83 (Table 5 ) as potent inhibitors of 5 -LO in cell-free assays with $\mathrm{IC}_{50}$ values $=0.2-1 \mu \mathrm{M}$. In intact cells, ardisiaquinone A 74, the most potent analogue in cell-free assays was less efficient $\left(\mathrm{IC}_{50}=\right.$ $5.56 \mu \mathrm{M})$ [146]. Structurally related compounds with extended alkyl, alkylene or isoprenyl residues such as chromenols 82 from Ircina spinosula [147] or atracylochromene 80 and 2-[(2E)3,7-dimethyl-2,6-octadienyl]-6-methyl-2,5-cyclohexadiene-1,4- dione $\mathbf{8 1}$ from Atractylodes lancea (Thunb.) [53], [118] might be superior, at least in intact cells ( $\mathrm{IC}_{50}=0.2-7.5 \mu \mathrm{M}$, see Table 5). Thymoquinone $\mathbf{7 7}$ and its polymer nigellone $\mathbf{7 8}$ from Nigella sativa (L.) that lack pronounced lipophilic residues are quite efficient as well [63], [148], [149]. Direct inhibition of 5-LO in cellfree assays was demonstrated for the ortho-quinone aethiopinone 79 from Salvia aethiopsis (L.) [150] and thymoquinone 77[63] with $\mathrm{IC}_{50}$ values of 0.11 and $3 \mu \mathrm{M}$, respectively, and both compounds suppressed 5-LO in activated leukocytes with comparable efficacies (Table 5). More detailed analysis of thymoquinone's 77 action revealed that, in addition to 5 - $\mathrm{LO}\left(\mathrm{IC}_{50}=3 \mu \mathrm{M}\right)$, it also blocks $\mathrm{LTC}_{4}$ synthase activity, albeit less potently $\left(\mathrm{IC}_{50}=10 \mu \mathrm{M}\right)$ [63], and aethiopinone 79 inhibited synovial $\mathrm{PLA}_{2}\left(\mathrm{IC}_{50}=10 \mu \mathrm{M}\right)$, but had no effects on COX enzymes [150]. Some of the investigated quinones e.g., thymoquinone 77, atracylochromene $\mathbf{8 0}$ and 2-[(2E)-3,7-dimethyl-2,6-octadienyl]-6-methyl-2,5-cyclohexadiene-1,4-dione $\mathbf{8 1}$ \} also inhibited COX-1 at about 10- or more-fold higher concentrations [53], [118], [148]. Recently, it was shown that i.p. administration of ardisiaquinone $\mathrm{A} \mathbf{7 4}$ to rats prevented the ischemia-induced increase in $\mathrm{LTB}_{4}$ in the liver with an $\mathrm{ID}_{50}=0.645 \mathrm{mg} / \mathrm{kg}$, 
Table 5 Quinones that inhibit 5-LO product synthesis

\begin{tabular}{|c|c|c|c|c|c|c|}
\hline No. & Compound & Structure & $I C_{50}$, intact & $I C_{50}$, cell-free & Plant & Ref. \\
\hline 74 & ardisiaquinone $\mathrm{A}$ & & $5.56 \mu \mathrm{M}$ & $\approx 0.2 \mu \mathrm{M}$ & Ardisia sieboldii & $\begin{array}{l}{[146],} \\
{[145]}\end{array}$ \\
\hline $\begin{array}{l}75 a ; \\
75 b \\
75 c ; \\
75 d\end{array}$ & $\begin{array}{l}\text { ardisia- } \\
\text { quinones } B, D \text {, } \\
E \text {, and } F\end{array}$ & & n.d. & $0.3-1 \mu \mathrm{M}$ & Ardisia sieboldii & [144] \\
\hline 76 & ardisianones & & n.d. & $\begin{array}{l}>80 \% \text { inhibition } \\
\text { at } 10 \mu \mathrm{M}\end{array}$ & Ardisia japonica & {$[142]$} \\
\hline $\begin{array}{l}77 \\
78\end{array}$ & $\begin{array}{l}\text { a) thymoquinone } \\
\text { b) nigellone = carbonyl } \\
\text { polymer of thymoquinone }\end{array}$ & & $\begin{array}{l}\text { a) } 0.26 \mu \mathrm{g} / \mathrm{mL} \text {; } \\
2.3 \mu \mathrm{M} ; \\
\text { b) } 11.9 \mu \mathrm{g} / \mathrm{mL}\end{array}$ & $\begin{array}{l}\text { a) } 3 \mu \mathrm{M} \text {; } \\
\text { b) n.d. }\end{array}$ & Nigella sativa & $\begin{array}{l}{[149],} \\
{[148],} \\
{[63]}\end{array}$ \\
\hline 79 & aethiopinone & & $0.2 \mu \mathrm{M}$ & $0.11 \mu \mathrm{M}$ & Salvia aethiopsis & $\begin{array}{l}{[150],} \\
{[227]}\end{array}$ \\
\hline 80 & atractylochromene & & $0.6 \mu \mathrm{M}$ & n.d. & Atractylodes lancea & [53] \\
\hline & & & & & & \\
\hline 83 & maesanin & & $0.7 \mu \mathrm{M}$ & n.d. & Maesa lanceolata & [143] \\
\hline
\end{tabular}

being slightly superior over AA-861 $1\left(\mathrm{ID}_{50}=0.728 \mathrm{mg} / \mathrm{kg}\right)$ [151].

\section{Pentacyclic triterpenes}

In general, triterpenes, consisting of six isoprene units, represent the basic structure of a large number of biological active compounds including steroid hormones, vitamin $\mathrm{D}$, heart-active "cardiac glycosides", steroid alkaloids, bile acids, and saponins. The pentacyclic triterpenes (PTs) are widely distributed among plants and, due to the complex biosynthesis including cyclization of squalene, only higher plants able to carry out this catalysis contain PTs. Many plants containing PTs, in particular boswellic acids (BAs) from Boswellia serrata, have been used as anti-inflammatory remedies in folk medicine (for review see [152], [153]).
In contrast to many other natural compounds that block 5-LO activity by chelating and redox actions, the PTs are assumed to act by a distinct mode, apparently by interference with a (regulatory) fatty acid-binding site of 5-LO [154], [155]. The most-recognized PTs that act on 5-LO are BAs, and many studies addressed the respective molecular interactions (for detailed review see [153], [156]). BAs with an 11-keto moiety, preferably 3-0-acteyl11-keto- $\beta$-BA (AKBA 89, Table $\mathbf{6}$ ) are of particular interest, and AKBA 89 is the most efficient derivative with $\mathrm{IC}_{50}$ values 1.5 $15 \mu \mathrm{M}$ in intact cells [74], [154], [157], [158], [159]. Studies using isolated 5-LO or other types of cell-free assays showed that AKBA 89 is a direct, non-redox-type 5-LO inhibitor $\left(\mathrm{IC}_{50}\right.$ values 8 $50 \mu \mathrm{M})$ [74], [154], [159]. The discrepancies in the potency of AKBA 89 for 5-LO inhibition $(1.5-50 \mu \mathrm{M})$ reported from different studies may be due to different experimental settings such as cell 
Table 6 Triterpenes and abietic acid that inhibit 5-LO product synthesis

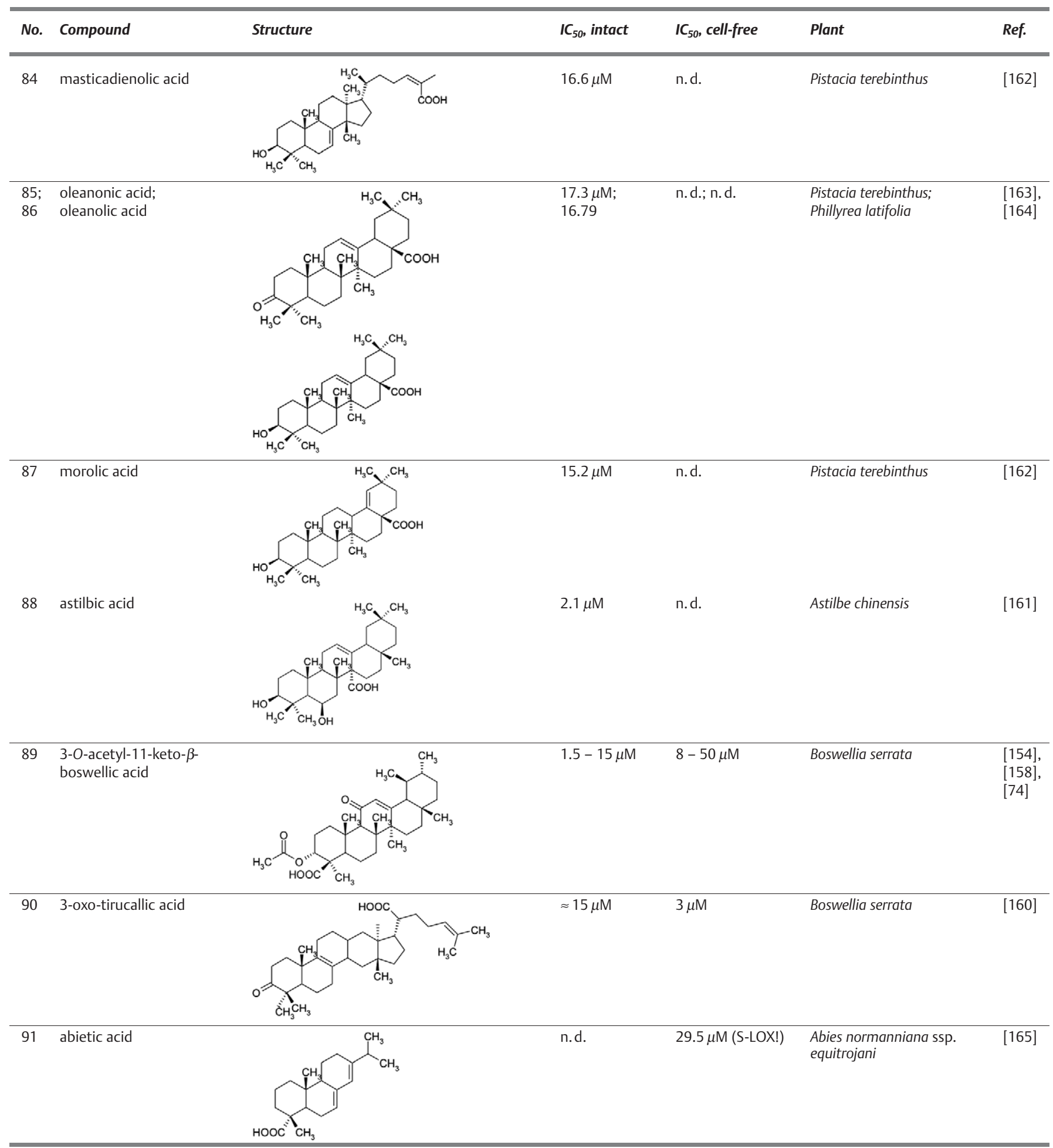

type, species and enzyme source (purified 5-LO, crude homogenates). It is obvious that AKBA $\mathbf{8 9}$ is more efficient in cell-based than in cell-free assays, suggesting additional actions in the intact cell, namely pro-oxidant activity that may irreversibly inactivate 5-LO [157]. Interestingly, the PT 3-oxotirucallic acid (3oxo-TA 90), also present in $B$. serrata, is more efficient on cellfree 5 - $\mathrm{LO}\left(\mathrm{IC}_{50}=3 \mu \mathrm{M}\right)$, whereas in intact cells 5 -LO product synthesis is even elevated at low concentrations, and a significant higher $\mathrm{IC}_{50}$ value $(15 \mu \mathrm{M})$ is evident [160].
Besides PTs from Boswellia species, the structurally related astilbic acid $\mathbf{8 8}$ (lacking the 11-keto group; Table $\mathbf{6}$ ) from Astilbe chinensis blocks 5-LO-dependent $\mathrm{LTC}_{4}$ generation in bone marrow-derived mast cells with $\mathrm{IC}_{50}=2.1 \mu \mathrm{M}$ [161], being equipotent to AKBA. Unfortunately, experiments addressing the effectiveness of astilbic acid $\mathbf{8 8}$ as a direct 5-LO inhibitor have not been performed yet. Similarly, the 11-keto-free PTs masticadienolic acid 84, oleanonic acid 85 and morolic acid 87 from Pistacia terebinthus (L.) [162], [163] or oleanolic acid 86 from 
Table 7 Sesquiterpenes that inhibit 5-LO product synthesis

\begin{tabular}{|c|c|c|c|c|c|c|}
\hline No. & Compound & Structure & $I C_{50}$, intact & $I C_{50}$, cell-free & Plant & Ref. \\
\hline 92 & parthenolide & & $12 \mu \mathrm{M}$ & n.d. & Tanacetum parthenium & [176] \\
\hline 93 & helenalin & & $9 \mu \mathrm{M}$ & n.d. & Arnica montana & {$[62]$} \\
\hline 94 & buddledin & & $50.4 \mu \mathrm{M}$ & n.d. & Buddleja spec. & {$[177]$} \\
\hline 97 & E-isolinaridial & & $0.42 \mu \mathrm{M}$ & $0.2 \mu \mathrm{M}$ & Linaria saxatilis var. glutinosa & [38] \\
\hline 98 & chamazulene & & $15 \mu \mathrm{M}$ & $10 \mu \mathrm{M}$ & Chamomilla recutita & {$[173]$} \\
\hline
\end{tabular}

Phillyrea latifolia (L.) [164] inhibit cellular 5-LO product synthesis with $\mathrm{IC}_{50}$ values 15.2 - 17.3 (Table 6 ), but data regarding 5LO inhibition in cell-free assays are not available. Finally, the tricyclic diterpenoid abietic acid $\mathbf{9 1}$ was found to inhibit soybean LO $\left(\right.$ IC $\left._{50}=29.5 \mu \mathrm{M}\right)$ but the effectiveness on mammalian 5-LO and cellular LT biosynthesis remains to be determined [165].

It was suggested that AKBA $\mathbf{8 9}$ acts at a selective binding site of 5-LO for various PTs that is different from the AA-binding cleft [155], where certain functional groups (i.e., the 11-keto and C4-carboxylic moiety) are essential for 5-LO inhibitory activity [166]. Although previous reports demonstrated a selectivity of BAs for 5-LO, we recently showed that AKBA 89 potently suppresses 12-LO product formation, with even higher potency in cell-free assays $\left(\mathrm{IC}_{50}=15 \mu \mathrm{M}\right)$ as compared to 5 - $\mathrm{LO}\left(\mathrm{IC}_{50}=\right.$ $50 \mu \mathrm{M})$ [167]. The direct interaction of AKBA 89 with platelet 12 -LO was visualized by a protein fishing approach using immobilized KBA as bait and platelet lysates as protein source, where 12-LO was specifically precipitated [167].

Taken together, PTs carrying a carbocylic group at varying positions may be effective in suppressing cellular 5-LO product formation. Although 5-LO seemingly possesses a specific PT-binding site, and BAs (i.e., AKBA 89) as well as 3-oxo-TA 90 directly inhibit 5-LO catalysis, it should be noted that PTs affect many sig- nal transduction pathways (e.g., MAPK, Akt, $\mathrm{Ca}^{2+}$ ) and effectors (i.e., reactive oxygen species) [157], [168], [169]. Hence, besides direct interference with 5-LO, these multiple (intra-)cellular targets and routes may be affected by PT that eventually governs inhibition of 5-LO product synthesis.

\section{Sesquiterpenes}

More than 3000 sesquiterpenes that all consist essentially of 3 isoprene units are known and most of them occur as polycycles, frequently with lactone, aldehyde or ketone functionality. Sesquiterpenes have long been recognized as anti-inflammatory agents being active in vitro and in vivo, and it is proposed that inhibition of NF- $\kappa \mathrm{B}$ and MAPK are molecular modes of actions (see [170], [171] and references therein). Chamazulene 98 (Table 7), an anti-inflammatory sesquiterpene from Chamomilla recutita (L.), is used to treat inflammatory skin and bowel diseases and was shown to scavenge hydroxyl radicals and to inhibit lipid peroxidation in vitro $\left(\mathrm{IC}_{50}=2-18 \mu \mathrm{M}\right)$ [172], [173]. At similar concentrations, chamazulene $\mathbf{9 8}$ inhibited $\mathrm{LTB}_{4}$ formation in intact cells and in corresponding cell-free supernatants with $\mathrm{IC}_{50}=15$ and $10 \mu \mathrm{M}$, respectively [173], whereas the structurally related sesquiterpene lactone matricin was not effective up to $200 \mu \mathrm{M}$. The most potent sesquiterpene reported thus far is E-isolinaridial 97 (Table 7), a sesquiterpene dialdehyde from Linaria saxatilis var. glutinosa that directly acts on 5-LO in cell-free as- 
Table 8 Alkaloids that inhibit 5-LO product synthesis

\begin{tabular}{|c|c|c|c|c|c|c|}
\hline No. & Compound & Structure & $I C_{50}$, intact & $I C_{50}$, cell-free & Plant & Ref. \\
\hline 99 & tryptanthrin & & $0.15 \mu \mathrm{M}$ & n.d. & Isatis tinctoria & [184] \\
\hline 100 & isaindigotone & & $<10 \mu \mathrm{M}$ & $0.04 \mu \mathrm{M}$ & Isatis indigotica & {$[185]$} \\
\hline 101 & quinolone alkaloids & & $10-14.6 \mu \mathrm{M}$ & n.d. & Evodia rutaecarpa & {$[183]$} \\
\hline 104 & goshuyuamide-II & & $6.6 \mu \mathrm{M}$ & n.d. & Evodia rutaecarpa & [182] \\
\hline 105 & colchicine & & $<10 \mu \mathrm{M}$ & no inhibition & Colchicum autumnale & $\begin{array}{l}{[179],} \\
{[180]}\end{array}$ \\
\hline
\end{tabular}

says $\left(\mathrm{IC}_{50}=0.2 \mu \mathrm{M}\right)$ as well as in intact neutrophils $\left(\mathrm{IC}_{50}=\right.$ $0.42 \mu \mathrm{M}$ ) [38]. Although E-isolinaridial 97 was equipotent in suppression of synovial $\mathrm{SPLA}_{2}$, no effects on COX enzymes, NOS or superoxide generation were evident. Similarly, the related sesquiterpene di- and trialdehydes miogadial 96 and miogatrial 95 from Zingiber mioga (Roscoe) inhibited 5-LO in cell-free assays [174], though less potently $\left(\mathrm{IC}_{50}=4\right.$ and $\left.7.5 \mu \mathrm{M}\right)$; unfortunately, the effectiveness in intact cells was not addressed. Possibly, the aldehyde groups may form adducts with susceptible thiol or primary amino moieties that are essential for 5-LO catalysis. Along these lines, we recently found that the synthetic thiol-reactive compound U-73122 (an aminosteroid with an electrophilic maleimide group, recognized as PLC inhibitor) potently inhibits 5-LO $\left(\mathrm{IC}_{50}=30 \mathrm{nM}\right)$ [175], apparently by covalent interaction with susceptible cysteine residues (unpublished data).

Among the sesquiterpene lactones, helenalin 93 from Arnica Montana [62] and parthenolide $\mathbf{9 2}$ from Tanacetum parthenium [176] interfere with 5-LO product synthesis. These agents usually act by forming covalent bonds via an $\alpha$-methylene- $\gamma$-lactone group with free thiol groups of cysteine residues in their target enzyme. Whereas for helenalin $\mathbf{9 3}$ detailed mechanistic analysis was performed that indicates a time-dependent inhibitory effect on 5-LO ( $\mathrm{IC}_{50}$ values in homogenates $<30 \mu \mathrm{M}$, in intact cells $9 \mu \mathrm{M}$ ), for parthenolide $\mathbf{9 2}$ the effectiveness was analyzed solely in intact cells $\left(\mathrm{IC}_{50}=12 \mu \mathrm{M}\right)$. The sesquiterpene ketone buddle- din 94, also possessing an exocyclic methylene group, was described as moderate blocker of 5-LO activity $\left(\mathrm{IC}_{50}=50.4 \mu \mathrm{M}\right)$ in rat peritoneal leukocytes [177]. Taken together, sesquiterpenes that inhibit 5-LO product formation encompass highly reactive compounds ( $\alpha$-methylene- $\gamma$-lactones, polyaldehydes) with antioxidant properties, but also with the ability to covalently modify susceptible moieties in their target protein, implying direct attack of 5-LO. Since most sesquiterpenes also interfere with other targets relevant for inflammation including NF- $\kappa \mathrm{B}, \mathrm{MAPK}$ and in particular PLA $\mathrm{A}_{2}$ and COX enzymes the extrapolation of 5-LO inhibition in vitro towards the anti-inflammatory activities in vivo needs more detailed analysis.

\section{Alkaloids}

Although there is substantial evidence for an anti-inflammatory effectiveness of alkaloids in vivo, only a few studies demonstrated suppression of 5-LO product synthesis by alkaloids. Colchicine 105 (Table 8) from Colchicum autumnale inhibits microtubule polymerization by binding to tubulin and has long been used for the treatment of gout and rheumatoid arthritis [178]. Reibmann et al. first showed that colchicine $\mathbf{1 0 5}$ (as well as vinblastine) inhibits ionophore-induced formation of $\mathrm{LTB}_{4}$ in neutrophils, linked to decrements in microtubule numbers [179]. Others confirmed that suppression of 5-LO product synthesis by colchicine 105 relies on microtubular disruption, but also on abrogation of agonist-induced increase in $\left[\mathrm{Ca}^{2+}\right]_{\mathrm{i}}$, connected to re- 
Table 9 Polyacetylenes as arachidonic acid mimetics that inhibit 5-LO product synthesis

\begin{tabular}{|c|c|c|c|c|c|c|}
\hline No. & Compound & Structure & $I C_{50}$, intact & $I C_{50}$, cell-free & Plant & Ref. \\
\hline $\begin{array}{l}106 ; \\
107\end{array}$ & $\begin{array}{l}\text { crepenynic acid; } \\
\text { ximenynic acid }\end{array}$ & & $\begin{array}{l}85 \mu \mathrm{M} \\
60 \mu \mathrm{M}\end{array}$ & n.d. & Ixiolaena brevicompta & [193] \\
\hline $\begin{array}{l}108 \\
109\end{array}$ & $\begin{array}{l}\text { cis-hexadec-11-ene-7,9- } \\
\text { diynoic acid; } \\
\text { cis-octadec-12-ene-7,9- } \\
\text { diynoic acid }\end{array}$ & & $\approx 5 \mu \mathrm{M}$ & n.d. & Heisteria accumniata & [195] \\
\hline 110 & falcarindol & & $9.4 \mu \mathrm{M}$ & $7 \mu \mathrm{M}$ & Saposhnikovia divaricata & $\begin{array}{l}{[196],} \\
{[52]}\end{array}$ \\
\hline 111 & panaxynol & $\mathrm{CH}_{2}$ & n.d. & $2 \mu \mathrm{M}$ & Saposhnikovia divaricata & [196] \\
\hline
\end{tabular}

duced AA release [180]. Importantly, the authors excluded that colchicine acts directly on 5-LO. Using intact bovine PMNL, the benzophenanthridine alkaloids sanguinarine $\mathbf{1 0 3}$ and chelerythrine 102 of Chelidonium majus (L.) were shown to inhibit 5$\mathrm{LO}\left(\mathrm{IC}_{50}=0.4\right.$ and $\left.0.8 \mu \mathrm{M}\right)$, apparently acting in a nonredox fashion [181]. However, only cell-based experiments were performed but no data from cell-free assays are available, and the related soybean LO-1 was hardly inhibited ( $\mathrm{IC}_{50}>75 \mu \mathrm{M}$ ) by these compounds. Therefore, and in view of the manifold actions of these alkaloids on central signaling molecules (that is, PKC) associated with 5-LO activation, a direct interference with 5-LO is uncertain. Similarly, different alkaloids isolated from Evodia rutaecarpa (Benth.) namely goshuyuamide-II 104 and five alkyl-/alkylenequinolone alkaloids reduced 5-LO activity in RBL-1 cells ( IC $_{50}$ goshuyuamide-II $=6.6 \mu \mathrm{M}$ ) [182] and in neutrophils (quinolone alkaloids) [183], but direct inhibition of 5-LO in cell-free assays was not addressed. Two structurally related alkaloids from Isatis species with a quinazolinone core, tryptanthrin 99 from I. tinctoria [184] and isaindigotone $\mathbf{1 0 0}$ from I. indigotica [185] have been shown to potently suppress 5 -LO in intact neutrophils ( IC $_{50}=0.15$ and $<10 \mu \mathrm{M}$, respectively). Isaindigotone $\mathbf{1 0 0}$ scavenges superoxide released by PMNL and inhibits cell-free 5-LO with an $\mathrm{IC}_{50}=0.04 \mu \mathrm{M}$. Both alkaloids also inhibited the formation of COX products and NOS-1, and tryptanthrin 99 has proven effective in certain animal models of inflammation [186], [187].

\section{Polyacetylenes as arachidonic acid mimetics}

Short after the discovery of the 5-LO enzyme, various AA derivatives, in particular those with acetylene moieties such as 5,8,11,14-eicosatetraynoic acid (ETYA) [65] and 5,8,11-eicosatriynoic acid [188], but also 15-hydro(pero)xy-5,8,11,13-eicosatetraenoic acid (15-H(P)ETE) [189,190], 5,12-diHETE, or LT-analogues like 5,6-methano-LTA 4 [191], [192] were found to inhibit 5LO activity. Moreover, AA-861 1 [2,3,5-trimethyl-6-(12-hydroxy5,10-dodecadiynyl)-1,4-benzoquinone, see above] contains two acetylene moieties in addition to the redox-active 1,4-benzoquinone structure [67].

A number of linear (poly)acetylenes consisting of C-16 to C-18 chains have been identified from various plants that inhibit 5 LO with rather moderate efficacy. Crepenynic acid 106 (cis-octadec-9-en-12-ynoic acid; Table 9) and ximenynic acid 107 (transoctadec-11-en-9-ynoic acid) from Ixiolaena brevicompta containing only one acetylene moiety inhibited 5-LO in intact leukocytes with $\mathrm{IC}_{50}$ values of 85 and $60 \mu \mathrm{M}$, respectively [193]. Derivatives containing more than one acetylene group, such as heptadeca$2 E, 8 E, 10 E, 16$-tetraene-4,6-diyne, heptadeca-2E,8Z,10E,16-tetraene-4,6-diyne, heptadeca-2E,8E,16-triene-4,6-diyne-10-ol, and safynol from Bidens campylotheca Schultz Bip. ssp campylotheca (Compositae) [194], or 11(S),16(R)-dihydroxy-octadeca-9Z,17diene-12,14-diyn-1-yl acetate from Angelica pubescens $f$. biserrata [52] are more efficient. Potent derivatives are cis-hexadec-11ene-7,9-diynoic acid $\mathbf{1 0 8}$ and cis-octadec-12-ene-7,9-diynoic acid 109 [195], falcarindol 110 and panaxynol 111 from Saposhnikoviae [52], [196] that block 5-LO product synthesis with $\mathrm{IC}_{50}$ values of $2-10 \mu \mathrm{M}$. All these compounds lack substantial antioxidant activities, and it is assumed that polyacetylenes bind to the active site of 5-LO, thereby competing with AA as substrate. Hence, it is not surprising that these compounds interfere with other AA-binding/metabolizing enzymes (i.e. COX and other LOs) as well.

\section{Diverse compounds suppressing 5-LO product synthesis}

Sulfur-containing molecules, e.g., certain cepaenes 114, ajoenes 112 and the thiosulfinate allicin $\mathbf{1 1 3}$ (Table 10) from Allium species (i.e., onions and garlic) were found to inhibit 5-LO activity in cell-based assays ( $\mathrm{IC}_{50}=0.5-1,1.5$ and $25 \mu \mathrm{M}$, respectively), as well as COX product $\left(\mathrm{TXB}_{2}\right.$ and $\left.\mathrm{PGE}_{2}\right)$ synthesis, and histamine release [197], [198]. No or only weak antioxidant properties have been reported for these compounds [199]. Unfortunately, no data are available demonstrating a direct inhibitory effect on 5-LO, 
Table 10 Diverse compounds that inhibit 5-LO product synthesis

\begin{tabular}{|c|c|c|c|c|c|c|}
\hline & Compound & Structure & $I C_{50}$, intact & $I C_{50}$, cell-free & Plant & Ref. \\
\hline 112 & ajoene & & $1.5 \mu \mathrm{M}$ & n.d. & Allium sativum & [198] \\
\hline 113 & allicin & & $25 \mu \mathrm{M}$ & n.d. & Allium sativum & [198] \\
\hline 115 & polyacetylenes & & $7.7-11.4 \mu \mathrm{M}$ & n.d. & Leontopodium alpinum & [201] \\
\hline
\end{tabular}

and analysis of a related allyl sulfide from onion showed only poor efficacy in inhibiting purified 5-LO $\left(\mathrm{IC}_{50}=83 \mu \mathrm{M}\right)$ [111]. Thus, the molecular mechanisms underlying suppression of 5LO product formation remain to be examined. Extracts of onions and garlic suppress inflammatory and allergic reactions in vivo (in animals as well as in human patients), correlating to the content of S-containing compounds [198], [200]. Recently, constituents (one lignan, one kaurenoate and three bisabolane derivatives) from the root of Leontopodium alpinum (Cass.) were shown to inhibit $\mathrm{LTB}_{4}$ synthesis in ionophore-activated granulocytes with $\mathrm{IC}_{50}$ values 7.7-11.4 $\mu \mathrm{M}$ [201]. No significant effect on COX activity was observed. Especially the bisabolane derivatives are remarkable, since the compounds comprise a novel type of structure that may interfere with 5-LO, however, cell-free assays were not applied in this study.

Nowadays, the efficient discovery of new lead structures as 5-LO inhibitors from the plant kingdom applies different strategies including ligand-based virtual filtering experiments using pharmacophore models, docking studies and neural networks [202]. For example, by virtual screening of a natural product collection and natural-product-derived combinatorial libraries (430 substances) for potential 5-LO inhibitors grounded on the "similarity principle", we identified 18 compounds which had mutual pharmacophore features with at least one of 43 known 5-LO inhibitors (that served as query structures) [203]. Two new chemotypes (116 and 117 in Fig. 4) strongly inhibited 5-LO in a cellbased and cell-free assay with $\mathrm{IC}_{50}$ values around 1 and $0.1 \mu \mathrm{M}$, respectively [203], demonstrating the potential of such naturalproduct-derived screening libraries for hit and lead structure identification.

\section{Conclusions}

Based on the pivotal pathophysiological role of 5-LO products in the development and maintenance of common and severe disor-

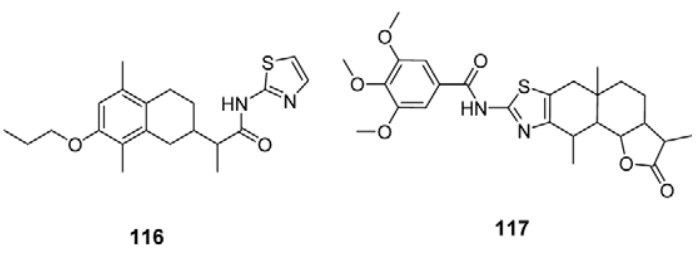

Fig. 4 Chemical structures of natural compounds that inhibit 5-LO product synthesis. The compounds $\mathbf{1 1 6}$ and 117 were identified by virtual screening of natural-product-derived combinatorial libraries (430 substances) grounded on the "similarity principle".

ders including bronchial asthma, rheumatoid arthritis, cancer, and cardiovascular diseases, the pharmacological intervention with 5-LO product formation is an important task, and accordingly, there is a strong need for efficient and selective 5-LO inhibitors. Although LT receptor antagonists (e.g., montelukast, pranlukast, zafirlukast) are nowadays frequently used in the therapy of bronchial asthma, and the synthetic 5-LO inhibitor zileuton has been approved for the treatment of asthma some years ago, at the moment, no 5-LO inhibitor is currently available on the market. The failure of many synthetic 5-LO inhibitors to enter the market have been attributed to the occurrence of severe side effects and the lack of efficacy. The latter point might be related to the complex regulation of 5-LO product synthesis in the cell and the influence of 5-LO activation by many co-factors such as phosphorylation, the redox tone, $\mathrm{Ca}^{2+}$ etc.

An enormous number of different plant-derived compounds from various species have been reported to interfere with 5-LO product formation. Whereas most studies have addressed the efficacy of a given test compound in a cell-based assay, considerably less reports have taken into account the molecular mechanisms by investigating a direct interference with 5-LO in cellfree assays, or even both test systems. Notably, besides direct inhibition of 5-LO, reduced 5-LO product synthesis in intact cells may result from many actions such as general cytotoxicity, inhi- 
bition of $\mathrm{LTA}_{4}$ hydrolase or $\mathrm{LTC}_{4}$ synthase (if applicable), inhibition of $\mathrm{PLA}_{2}$ and thus AA release, blockade of FLAP, interference with 5-LO kinases, $\mathrm{Ca}^{2+}$-mobilization, lipid interactions, and 5LO translocation/trafficking, as well as altering the cellular redox-tone. In general, it appears that lipophilic, often fatty acidlike compounds with (i.e., phenols) or without (i.e., triterpenes, polyacetylenes) reducing properties interfere with 5-LO, and the majority are phenolic structures including flavonoids, quinones (that become bio-activated to hydroquinones) hydroxylated coumarins, and many other polyphenols. Apparently, the combination of iron-reducing and iron-chelating features of these phenolic compounds (particularly ortho-dihydroxy moieties) are responsible for 5-LO inhibition, but still structural aspects play a role, in particular, prenyl residues or extended alkyl chains seem to govern the efficacy. Many phenolic compounds (and plant extracts containing them) are recognized and used as anti-inflammatory remedies and inhibition of 5-LO product synthesis might be one underlying mode of action. However, the poor bioavailability and the rapid metabolism and elimination of polyphenols after oral intake raises doubts regarding their effectiveness as 5-LO inhibitors in vivo. Also, the low selectivity of phenolic substances (for example, many inhibit COX, 12-LO and $\mathrm{PLA}_{2}$ ) makes it difficult to correlate the 5-LO inhibitory effects in vitro to an anti-inflammatory action in vivo. Among the non-reducing compounds, the boswellic acids have been intensively studied, but still, important questions regarding the molecular mode of action and the contribution of 5-LO inhibition for the in vivo pharmacology remain open. Similarly, for alkaloids and sesquiterpenes that may inhibit 5-LO activity in a non-redox fashion, the molecular interactions with 5-LO catalysis are unclear. Finally, many of the plant-derived compounds exhibit only a moderate potency and respective plasma or tissue concentrations reached in patients taking such medication (if known at all) are often significantly lower.

Altogether, a huge number of studies demonstrating suppression of 5 -LO product synthesis by plant-derived compounds have been conducted and published, but considerably less investigations have been performed that provide deeper insights into mechanistic interactions of the compounds with 5-LO. Most available data do not allow final conclusions about the in vivo relevance of 5-LO inhibition with respect to intervention with allergic or inflammatory diseases. Nevertheless, carefully performed contributions led to the identification of plant-derived compounds that potently interfere with 5-LO activity in intact cells as well as in cell-free assays. These discoveries encourage the future search of plant-derived compounds as 5-LO inhibitors and provide a suitable basis for pharmaceutical chemists for novel developments.

\section{Acknowledgements}

The author's studies were supported by grants from the Deutsche Forschungsgemeinschaft, Pharmasan GmbH (Freiburg, Germany), and the European Union EU (QLG1-CT-2001-01521 and LSHM-CT-2004-005033).

\section{References}

1 Funk CD. Prostaglandins and leukotrienes: advances in eicosanoid biology. Science 2001; 294: 1871-5.

2 Werz 0.5-lipoxygenase: cellular biology and molecular pharmacology. Curr Drug Targets Inflamm Allergy 2002; 1: 23-44.

3 Folco G, Murphy RC. Eicosanoid transcellular biosynthesis: from cellcell interactions to in vivo tissue responses. Pharmacol Rev 2006; 58: $375-88$.

4 Serhan C. Lipoxins and aspirin-triggered 15-epi-lipoxins. In: Gallin JL, Syndermann R, editors. Inflammation. Basic principles and clinical correlates Philadelphia: Lipincott Williams \& Williams; 1999.

5 Claesson HE, Dahlen SE. Asthma and leukotrienes: antileukotrienes as novel anti-asthmatic drugs. J Intern Med 1999; 245: 205 - 27.

6 Brink C, Dahlen SE, Drazen J, Evans JF, Hay DW, Nicosia S et al. International Union of Pharmacology XXXVII. Nomenclature for leukotriene and lipoxin receptors. Pharmacol Rev 2003; 55: 195-227.

7 Kemp JP. Recent advances in the management of asthma using leukotriene modifiers. Am J Respir Med 2003; 2: 139-56.

8 Yokomizo T, Izumi T, Chang K, Takuwa Y, Shimizu T. A G-protein-coupled receptor for leukotriene B4 that mediates chemotaxis. Nature 1997; 387: 620 - 4 .

9 Okuno T, Yokomizo T, Hori T, Miyano M, Shimizu T. Leukotriene B4 receptor and the function of its helix 8. J Biol Chem 2005; 280: $32049-$ 52.

10 Brink C, Dahlen SE, Drazen J, Evans JF, Hay DW, Rovati GE et al. International Union of Pharmacology XLIV. Nomenclature for the oxoeicosanoid receptor. Pharmacol Rev 2004; 56: 149- 57.

11 Powell WS, Rokach J. Biochemistry, biology and chemistry of the 5-lipoxygenase product 5-oxo-ETE. Prog Lipid Res 2005; 44: 154-83.

12 Muro S, Hamid Q, Olivenstein R, Taha R, Rokach J, Powell WS. 5-Oxo6,8,11,14-eicosatetraenoic acid induces the infiltration of granulocytes into human skin. J Allergy Clin Immunol 2003; 112: 768 - 74.

13 Werz O, Steinhilber D. Therapeutic options for 5-lipoxygenase inhibitors. Pharmacol Ther 2006; 112: $701-18$.

14 Garcia C, Boyce BF, Gilles J, Dallas M, Qiao M, Mundy GR et al. Leukotriene B4 stimulates osteoclastic bone resorption both in vitro and in vivo. J Bone Miner Res 1996; 11: 1619-27.

15 Bonewald LF, Flynn M, Qiao M, Dallas MR, Mundy GR, Boyce BF. Mice lacking 5-lipoxygenase have increased cortical bone thickness. Adv Exp Med Biol 1997; 433: 299-302.

16 Avis I, Hong SH, Martinez A, Moody T, Choi YH, Trepel J et al. Five-lipoxygenase inhibitors can mediate apoptosis in human breast cancer cell lines through complex eicosanoid interactions. Faseb J 2001; 15 : 2007-9.

17 Romano M, Catalano A, Nutini M, D’Urbano E, Crescenzi C, Claria J et al. 5-Lipoxygenase regulates malignant mesothelial cell survival: involvement of vascular endothelial growth factor. Faseb J 2001; 15 : 2326-36.

18 Ghosh J, Myers CE. Inhibition of arachidonate 5-lipoxygenase triggers massive apoptosis in human prostate cancer cells. Proc Natl Acad Sci U S A 1998; 95: 13182 - 7.

19 Mehrabian M, Allayee H. 5-Lipoxygenase and atherosclerosis. Curr Opin Lipidol 2003; 14: 447-57.

20 Funk CD. Leukotriene modifiers as potential therapeutics for cardiovascular disease. Nat Rev Drug Discov 2005; 4: 664-72.

21 Rådmark $\mathrm{O}$, Werz $\mathrm{O}$, Steinhilber D, Samuelsson B. 5-Lipoxygenase: regulation of expression and enzyme activity. Trends Biochem Sci 2007; 32: $332-41$.

22 Steinhilber D. 5-Lipoxygenase: a target for anti-inflammatory drugs revisited. Curr Med Chem 1999; 6: 69-83.

23 Werz O, Tretiakova I, Michel A, Ulke-Lemee A, Hornig M, Franke L et al. Caspase-mediated degradation of human 5-lipoxygenase in B lymphocytic cells. Proc Natl Acad Sci U S A 2005; 102: 13164 - 9.

24 Werz O, Steinhilber D. Development of 5-lipoxygenase inhibitors lessons from cellular enzyme regulation. Biochem Pharmacol 2005; 70: $327-33$.

25 Hammarberg T, Provost P, Persson B, Rådmark O. The N-terminal domain of 5-lipoxygenase binds calcium and mediates calcium stimulation of enzyme activity. J Biol Chem 2000; 275: 38 787-93.

26 Hemak J, Gale D, Brock TG. Structural characterization of the catalytic domain of the human 5-lipoxygenase enzyme. J Mol Model 2002; 8: $102-12$. 
27 Allard JB, Brock TG. Structural organization of the regulatory domain of human 5-lipoxygenase. Curr Protein Pept Sci 2005; 6: 125-31.

28 Rådmark O. Arachidonate 5-lipoxygenase. J Lipid Mediat Cell 1995; 12: $171-84$.

29 Hornig C, Albert D, Fischer L, Hornig M, Rådmark O, Steinhilber D et al. 1-Oleoyl-2-acetylglycerol stimulates 5-lipoxygenase activity via a putative (phospho)lipid binding site within the N-terminal C2-like domain. J Biol Chem 2005; 280: 26913 - 21.

30 Kulkarni S, Das S, Funk CD, Murray D, Cho W. Molecular basis of the specific subcellular localization of the C2-like domain of 5-lipoxygenase. J Biol Chem 2002; 277: 13167- 74.

31 Rådmark O, Samuelsson B. Regulation of 5-lipoxygenase enzyme activity. Biochem Biophys Res Commun 2005; 338: 102 - 10.

32 Chen XS, Funk CD. The N-terminal "beta-barrel" domain of 5-lipoxygenase is essential for nuclear membrane translocation. J Biol Chem 2001; 276: $811-8$.

33 Brock TG. Regulating leukotriene synthesis: the role of nuclear 5-lipoxygenase. J Cell Biochem 2005; 96: 1203-11.

34 Gijon MA, Leslie CC. Regulation of arachidonic acid release and cytosolic phospholipase A2 activation. J Leukoc Biol 1999; 65: 330-6.

35 Hamasaki Y, Kobayashi I, Zaitu M, Tsuji K, Kita M, Hayasaki R et al. Magnolol inhibits leukotriene synthesis in rat basophilic leukemia2H3 cells. Planta Med 1999; 65: 222 -6.

36 Ferrandiz ML, Gil B, Sanz MJ, Ubeda A, Erazo S, Gonzalez E et al. Effect of bakuchiol on leukocyte functions and some inflammatory responses in mice. J Pharm Pharmacol 1996; 48: 975-80.

37 Cabre F, Carabaza A, Suesa N, Garcia AM, Rotllan E, Gomez M et al. Effect of manoalide on human 5-lipoxygenase activity. Inflamm Res 1996; 45: 218-23.

38 Benrezzouk R, Terencio MC, Ferrandiz ML, San Feliciano A, Gordaliza M, Miguel del Corral JM et al. Inhibition of human sPLA2 and 5-lipoxygenase activities by two neo-clerodane diterpenoids. Life Sci 1999; 64: PL205-11.

39 Hong J, Bose M, Ju J, Ryu JH, Chen X, Sang S et al. Modulation of arachidonic acid metabolism by curcumin and related beta-diketone derivatives: effects on cytosolic phospholipase $A(2)$, cyclooxygenases and 5-lipoxygenase. Carcinogenesis 2004; 25: 1671-9.

40 Son JK, Son MJ, Lee E, Moon TC, Son KH, Kim CH et al. Ginkgetin, a biflavone from Ginko biloba leaves, inhibits cyclooxygenases-2 and 5-lipoxygenase in mouse bone marrow-derived mast cells. Biol Pharm Bull 2005; 28: 2181 - 4 .

41 Lombardo D, Dennis EA. Cobra venom phospholipase A2 inhibition by manoalide. A novel type of phospholipase inhibitor. J Biol Chem 1985; 260: $7234-40$.

42 De Vries GW, Amdahl L, Mobasser A, Wenzel M, Wheeler LA. Preferential inhibition of 5-lipoxygenase activity by manoalide. Biochem Pharmacol 1988; 37: 2899-905.

43 McColl SR, Krump E, Naccache PH, Poubelle PE, Braquet P, Braquet M et al. Granulocyte-macrophage colony-stimulating factor increases the synthesis of leukotriene B4 by human neutrophils in response to platelet-activating factor. Enhancement of both arachidonic acid availability and 5-lipoxygenase activation. J Immunol 1991; 146: $1204-11$.

44 Peters-Golden M, Brock TG. 5-lipoxygenase and FLAP. Prostaglandins Leukot Essent Fatty Acids 2003; 69: 99-109.

45 Luo M, Jones SM, Peters-Golden M, Brock TG. Nuclear localization of 5-lipoxygenase as a determinant of leukotriene B4 synthetic capacity. Proc Natl Acad Sci U S A 2003; 100: 12165- 70.

46 Wube AA, Bucar F, Asres K, Gibbons S, Adams M, Streit B et al. Knipholone, a selective inhibitor of leukotriene metabolism. Phytomedicine 2006; 13: $452-6$.

47 Lepley RA, Muskardin DT, Fitzpatrick FA. Tyrosine kinase activity modulates catalysis and translocation of cellular 5-lipoxygenase. J Biol Chem 1996; 271: 6179-84.

48 Burkert E, Arnold C, Hammarberg T, Rådmark O, Steinhilber D, Werz $\mathrm{O}$. The C2-like beta-barrel domain mediates the $\mathrm{Ca}^{2+}$-dependent resistance of 5-lipoxygenase activity against inhibition by glutathione peroxidase-1. J Biol Chem 2003; 278: 42846 - 53.

49 Lee SH, Son MJ, Ju HK, Lin CX, Moon TC, Choi HG et al. Dual inhibition of cyclooxygenases-2 and 5-lipoxygenase by deoxypodophyllotoxin in mouse bone marrow-derived mast cells. Biol Pharm Bull 2004; 27: $786-8$.
50 Chao YY, Su W, Jan CR, Ko YC, Chen JJ, Cheng JS et al. Novel action of lignans isolated from Hernandia nymphaeifolia on Ca2+ signaling in human neutrophils. Arch Toxicol 2002; 75: 695- 702.

51 Ko FN, Wu TS, Liou MJ, Huang TF, Teng CM. Vasorelaxation of rat thoracic aorta caused by osthole isolated from Angelica pubescens. Eur J Pharmacol 1992; 219: 29-34.

52 Liu JH, Zschocke S, Reininger E, Bauer R. Inhibitory effects of Angelica pubescens f. biserrata on 5-lipoxygenase and cyclooxygenase. Planta Med 1998; 64: 525-9.

53 Resch M, Steigel A, Chen ZL, Bauer R. 5-Lipoxygenase and cyclooxygenase-1 inhibitory active compounds from Atractylodes lancea. J Nat Prod 1998; 61: $347-50$.

54 Werz O, Burkert E, Fischer L, Szellas D, Dishart D, Samuelsson B et al. Extracellular signal-regulated kinases phosphorylate 5-lipoxygenase and stimulate 5-lipoxygenase product formation in leukocytes. Faseb J 2002; 16: $1441-3$.

55 Werz O, Szellas D, Steinhilber D, Rådmark O. Arachidonic acid promotes phosphorylation of 5-lipoxygenase at Ser-271 by MAPKactivated protein kinase 2 (MK2). J Biol Chem 2002; 277: 14793 - 800.

56 Werz O, Klemm J, Samuelsson B, Rådmark O. 5-Lipoxygenase is phosphorylated by p38 kinase-dependent MAPKAP kinases. Proc Natl Acad Sci U S A 2000; 97: 5261 -6.

57 Luo M, Jones SM, Phare SM, Coffey MJ, Peters-Golden M, Brock TG. Protein kinase A inhibits leukotriene synthesis by phosphorylation of 5-lipoxygenase on serine 523. J Biol Chem 2004; 279: 41512-20.

58 Cho SY, Park SJ, Kwon MJ, Jeong TS, Bok SH, Choi WY et al. Quercetin suppresses proinflammatory cytokines production through MAP kinases andNF-kappaB pathway in lipopolysaccharide-stimulated macrophage. Mol Cell Biochem 2003; 243: 153-60.

59 Wadsworth TL, McDonald TL, Koop DR. Effects of Ginkgo biloba extract (EGb 761) and quercetin on lipopolysaccharide-induced signaling pathways involved in the release of tumor necrosis factor-alpha. Biochem Pharmacol 2001; 62: 963-74.

60 Dell'Agli M, Galli GV, Bosisio E. Inhibition of cGMP-phosphodiesterase- 5 by biflavones of Ginkgo biloba. Planta Med 2006; 72: 468 - 70.

61 Penning TD. Inhibitors of leukotriene A4 (LTA4) hydrolase as potential anti-inflammatory agents. Curr Pharm Des 2001; 7: 163 - 79.

62 Tornhamre S, Schmidt TJ, Nasman-Glaser B, Ericsson I, Lindgren JA. Inhibitory effects of helenalin and related compounds on 5-lipoxygenase and leukotriene $C(4)$ synthase in human blood cells. Biochem Pharmacol 2001; 62: 903-11.

63 Mansour M, Tornhamre S. Inhibition of 5-lipoxygenase and leukotriene C4 synthase in human blood cells by thymoquinone. J Enzyme Inhib Med Chem 2004; 19: 431-6.

64 Orning L, Hammarstrom S. Inhibition of leukotriene C and leukotriene D biosynthesis. J Biol Chem 1980; 255: 8023-6.

65 Bokoch GM, Reed PW. Evidence for inhibition of leukotriene A4 synthesis by $5,8,11,14$-eicosatetraynoic acid in guinea pig polymorphonuclear leukocytes. J Biol Chem 1981; 256: 4156 - 9.

66 Uozumi N, Kume K, Nagase T, Nakatani N, Ishii S, Tashiro F et al. Role of cytosolic phospholipase $\mathrm{A}(2)$ in allergic response and parturition. Nature 1997; 390: 618-22.

67 Yoshimoto T, Yokoyama C, Ochi K, Yamamoto S, Maki Y, Ashida Y et al. 2,3,5-Trimethyl-6-(12-hydroxy-5,10-dodecadiynyl)-1,4-benzoquinone (AA861), a selective inhibitor of the 5-lipoxygenase reaction and the biosynthesis of slow-reacting substance of anaphylaxis. Biochim Biophys Acta 1982; 713: 470-3.

68 Ford-Hutchinson AW, Gresser M, Young RN. 5-Lipoxygenase. Annu Rev Biochem 1994; 63: 383-417.

69 McMillan RM, Walker ERH. Designing therapeutically effective 5-lipoxygenase inhibitors. Trends Pharmacol Sci 1992; 13: 323 - 30.

70 Carter GW, Young PR, Albert DH, Bouska J, Dyer R, Bell RL et al. 5-Lipoxygenase inhibitory activity of zileuton. J Pharmacol Exp Ther 1991; 256: 929- 37.

71 Tateson JE, Randall RW, Reynolds CH, Jackson WP, Bhattacherjee P, Salmon JA et al. Selective inhibition of arachidonate 5-lipoxygenase by novel acetohydroxamic acids: biochemical assessment in vitro and ex vivo. Br J Pharmacol 1988; 94: 528-39.

72 Drazen JM. Asthma therapy with agents preventing leukotriene synthesis or action. Proc Assoc Am Physicians 1999; 111: 547 - 59.

73 Weinblatt ME, Kremer JM, Coblyn JS, Helfgott S, Maier AL, Petrillo G et al. Zileuton, a 5-lipoxygenase inhibitor in rheumatoid arthritis. J Rheumatol 1992; 19: 1537-41. 
74 Werz O, Szellas D, Henseler M, Steinhilber D. Nonredox 5-lipoxygenase inhibitors require glutathione peroxidase for efficient inhibition of 5-lipoxygenase activity. Mol Pharmacol 1998; 54: 445-51.

75 Fischer L, Szellas D, Radmark O, Steinhilber D, Werz O. Phosphorylation- and stimulus-dependent inhibition of cellular 5-lipoxygenase activity by nonredox-type inhibitors. Faseb J 2003; 17: 949- 51

76 Fischer L, Steinhilber D, Werz O. Molecular pharmacological profile of the non-redox-type 5-lipoxygenase inhibitor $\mathrm{CJ}-13,610$. Br J Pharmacol 2004; 142: 861 - 8 .

77 Werz O, Steinhilber D. Pharmacological intervention with 5-lipoxygenase: new insights and novel compounds. Exp Opin Ther Patents 2005; 15 : 505 - 19 .

78 Laufer S, Tries S, Augustin J, Dannhardt G. Pharmacological profile of a new pyrrolizine derivative inhibiting the enzymes cyclo-oxygenase and 5-lipoxygenase. Arzneimittelforschung 1994; 44: 629-36.

79 Qian C, Hwang SB, Libertine-Garahan L, Eckman JB, Cai X, Scannell RT et al. Anti-inflammatory activities of LDP-392, a dual PAF receptor antagonist and 5-lipoxygenase inhibitor. Pharmacol Res 2001; 44: $213-20$.

80 Lewis TA, Bayless L, Dipesa AJ, Eckman JB, Gillard M, Libertine L et al. 5 -Lipoxygenase inhibition by $\mathrm{N}$-hydroxycarbamates in dual-function compounds. Bioorg Med Chem Lett 2005; 15: 1083-5.

81 Lewis TA, Bayless L, Eckman JB, Ellis JL, Grewal G, Libertine L et al. 5Lipoxygenase inhibitors with histamine $\mathrm{H}(1)$ receptor antagonist activity. Bioorg Med Chem Lett 2004; 14: 2265-8.

82 Dixon RAF, Diehl RE, Opas E, Rands E, Vickers PJ, Evans JF et al. Requirement of a 5-lipoxygenase-activating protein for leukotriene synthesis. Nature 1990; 343: $282-4$

83 Byrum RS, Goulet JL, Griffiths RJ, Koller BH. Role of the 5-lipoxygenase-activating protein (FLAP) in murine acute inflammatory responses. J Exp Med 1997; 185: 1065 - 75.

84 Gillard J, Ford-Hutchinson AW, Chan C, Charleson S, Denis D, Foster A et al. L-663,536 (MK-886) (3-(1-(4-chlorobenzyl)-3-t-butyl-thio-5isopropylindol-2-yl)-2,2-dimethylpropanoic acid), a novel, orally active leukotriene biosynthesis inhibitor. Can J Physiol Pharmacol 1989; 67: $456-64$.

85 Depre M, Friedman B, Tanaka W, Van Hecken A, Buntinx A, DeSchepper PJ. Biochemical activity, pharmacokinetics, and tolerability of MK-886, a leukotriene biosynthesis inhibitor, in humans. Clin Pharmacol Ther 1993; 53: $602-7$.

86 Fruchtmann R, Mohrs KH, Hatzelmann A, Raddatz S, Fugmann B, Junge B et al. In vitro pharmacology of BAY X1005, a new inhibitor of leukotriene synthesis. Agents Actions 1993; 38: 188-95.

87 Brideau C, Chan C, Charleson S, Denis D, Evans JF, Ford-Hutchinson AW et al. Pharmacology of MK-0591 (3-[1-(4-chlorobenzyl)-3-(t-butylthio)-5-(quinolin-2-yl-methoxy)-indol-2-yl]-2,2-dimethylpropanoic acid), a potent, orally active leukotriene biosynthesis inhibitor. Can J Physiol Pharmacol 1992; 70: 799-807.

88 Charleson S, Evans JF, Leger S, Perrier H, Prasit P, Wang ZY et al. Structural requirements for the binding of fatty acids to 5-lipoxygenaseactivating protein. Eur J Pharmacol Mol Pharm 1994; 267: 275-80.

89 Koshihara Y, Neichi T, Murota S, Lao A, Fujimoto Y, Tatsuno T. Selective inhibition of 5-lipoxygenase by natural compounds isolated from Chinese plants, Artemisia rubripes Nakai. FEBS Lett 1983; 158: 41 - 4

90 Neichi T, Koshihara Y, Murota S. Inhibitory effect of esculetin on 5-lipoxygenase and leukotriene biosynthesis. Biochim Biophys Acta 1983; 753: $130-2$.

91 Yoshimoto T, Furukawa M, Yamamoto S, Horie T, Watanabe-Kohno S. Flavonoids: potent inhibitors of arachidonate 5-lipoxygenase. Biochem Biophys Res Commun 1983; 116: 612 -8.

92 Kuhl P, Shiloh R, Jha H, Murawski U, Zilliken F. 6,7,4'-Trihydroxyisoflavan: a potent and selective inhibitor of 5-lipoxygenase in human and porcine peripheral blood leukocytes. Prostaglandins 1984; 28: 783 804.

93 Kimura Y, Okuda H, Arichi S. Effects of stilbenes on arachidonate metabolism in leukocytes. Biochim Biophys Acta 1985; 834: 275 -8.

94 Yoon JH, Baek SJ. Molecular targets of dietary polyphenols with antiinflammatory properties. Yonsei Med J 2005; 46: 585-96.

95 Kuhnau J. The flavonoids. A class of semi-essential food components: their role in human nutrition. World Rev Nutr Diet 1976; 24: 117-91.

96 Rahman I, Biswas SK, Kirkham PA. Regulation of inflammation and redox signaling by dietary polyphenols. Biochem Pharmacol 2006; 72: $1439-52$
97 Kim HP, Son KH, Chang HW, Kang SS. Anti-inflammatory plant flavonoids and cellular action mechanisms. J Pharmacol Sci 2004; 96: 229-45.

98 Butenko IG, Gladtchenko SV, Galushko SV. Anti-inflammatory properties and inhibition of leukotriene C4 biosynthesis in vitro by flavonoid baicalein from Scutellaria baicalensis georgy roots. Agents Actions 1993; 39: C49-51.

99 Hiermann A, Schramm HW, Laufer S. Anti-inflammatory activity of myricetin-3-O-beta-D-glucuronide and related compounds. Inflamm Res 1998; 47: $421-7$.

100 Ferrandiz ML, Alcaraz MJ. Anti-inflammatory activity and inhibition of arachidonic acid metabolism by flavonoids. Agents Actions 1991; 32: $283-8$

${ }^{101}$ Kim HR, Pham HT, Ziboh VA. Flavonoids differentially inhibit guinea pig epidermal cytosolic phospholipase A2. Prostaglandins Leukot Essent Fatty Acids 2001; 65: 281 -6.

102 Chang HW, Baek SH, Chung KW, Son KH, Kim HP, Kang SS. Inactivation of phospholipase A2 by naturally occurring biflavonoid, ochnaflavone. Biochem Biophys Res Commun 1994; 205: 843-9.

${ }^{103}$ Kwak WJ, Moon TC, Lin CX, Rhyn HG, Jung H, Lee E et al. Papyriflavonol A from Broussonetia papyrifera inhibits the passive cutaneous anaphylaxis reaction and has a secretory phospholipase A2-inhibitory activity. Biol Pharm Bull 2003; 26: 299-302.

${ }^{104}$ Fawzy AA, Vishwanath BS, Franson RC. Inhibition of human non-pancreatic phospholipases A2 by retinoids and flavonoids. Mechanism of action. Agents Actions 1988; 25: 394-400.

105 Chi YS, Jong HG, Son KH, Chang HW, Kang SS, Kim HP. Effects of naturally occurring prenylated flavonoids on enzymes metabolizing arachidonic acid: cyclooxygenases and lipoxygenases. Biochem Pharmacol 2001; 62: 1185 - 91.

${ }^{106}$ Bas E, Recio MC, Giner RM, Manez S, Cerda-Nicolas M, Rios JL. Antiinflammatory activity of 5-O-demethylnobiletin, a polymethoxyflavone isolated from Sideritis tragoriganum. Planta Med 2006; 72 : $136-42$.

107 Sies H, Schewe T, Heiss C, Kelm M. Cocoa polyphenols and inflammatory mediators. Am J Clin Nutr 2005; 81: 304S-12S.

108 Odontuya G, Hoult JR, Houghton PJ. Structure-activity relationship for anti-inflammatory effect of luteolin and its derived glycosides. Phytother Res 2005; 19: 782-6.

${ }^{109}$ Laughton MJ, Evans PJ, Moroney MA, Hoult JR, Halliwell B. Inhibition of mammalian 5-lipoxygenase and cyclo-oxygenase by flavonoids and phenolic dietary additives. Relationship to antioxidant activity and to iron ion-reducing ability. Biochem Pharmacol 1991; 42: $1673-81$.

110 Riendeau D, Falgueyret JP, Nathaniel DJ, Rokach J, Ueda N, Yamamoto S. Sensitivity of immunoaffinity-purified porcine 5-lipoxygenase to inhibitors and activating lipid hydroperoxides. Biochem Pharmacol 1989; 38: 2313 - 21 .

111 Prasad NS, Raghavendra R, Lokesh BR, Naidu KA. Spice phenolics inhibit human PMNL 5-lipoxygenase. Prostaglandins Leukot Essent Fatty Acids 2004; 70: $521-8$.

112 Reddy GR, Ueda N, Hada T, Sackeyfio AC, Yamamoto S, Hano Y et al. A prenylflavone, artonin $\mathrm{E}$, as arachidonate 5-lipoxygenase inhibitor. Biochem Pharmacol 1991; 41: 115 - 8.

113 Njamen D, Mbafor JT, Fomum ZT, Kamanyi A, Mbanya JC, Recio MC et al. Anti-inflammatory activities of two flavanones, sigmoidin A and sigmoidin B, from Erythrina sigmoidea. Planta Med 2004; 70: $104-7$.

114 Schramm DD, Wang JF, Holt RR, Ensunsa JL, Gonsalves JL, Lazarus SA et al. Chocolate procyanidins decrease the leukotriene-prostacyclin ratio in humans and human aortic endothelial cells. Am J Clin Nutr 2001; 73: 36-40.

115 Flynn DL, Rafferty MF, Boctor AM. Inhibition of human neutrophil 5lipoxygenase activity by gingerdione, shogaol, capsaicin and related pungent compounds. Prostaglandins Leukot Med 1986; 24: $195-8$.

116 Kiuchi F, Iwakami S, Shibuya M, Hanaoka F, Sankawa U. Inhibition of prostaglandin and leukotriene biosynthesis by gingerols and diarylheptanoids. Chem Pharm Bull (Tokyo) 1992; 40: 387-91.

117 Miller DK, Sadowski S, Han GQ, Joshua H. Identification and isolation of medicarpin and a substituted benzofuran as potent leukotriene inhibitors in an anti-inflammatory Chinese herb. Prostaglandins Leukot Essent Fatty Acids 1989; 38: 137-43.

118 Resch M, Heilmann J, Steigel A, Bauer R. Further phenols and polyacetylenes from the rhizomes of Atractylodes lancea and their anti-inflammatory activity. Planta Med 2001; 67: 437-42. 
119 Albert D, Zundorf I, Dingermann T, Muller WE, Steinhilber D, Werz O. Hyperforin is a dual inhibitor of cyclooxygenase-1 and 5-lipoxygenase. Biochem Pharmacol 2002; 64: 1767-75.

${ }^{120}$ Koshihara Y, Fujimoto Y, Inoue H. A new 5-lipoxygenase selective inhibitor derived from Artocarpus communis strongly inhibits arachidonic acid-induced ear edema. Biochem Pharmacol 1988; 37: 2161 5.

${ }^{121}$ Prieto JM, Giner RM, Recio Mf MC, Schinella G, Manez S, Rios JL. Diphyllin acetylapioside, a 5-lipoxygenase inhibitor from Haplophyllum hispanicum. Planta Med 2002; 68: 359-60.

122 Kohyama N, Nagata T, Fujimoto S, Sekiya K. Inhibition of arachidonate lipoxygenase activities by 2-(3,4-dihydroxyphenyl)ethanol, a phenolic compound from olives. Biosci Biotechnol Biochem 1997; 61: 347 50 .

123 de la Puerta R, Ruiz Gutierrez V, Hoult JR. Inhibition of leukocyte 5lipoxygenase by phenolics from virgin olive oil. Biochem Pharmacol 1999; 57: 445 - 9 .

${ }^{124}$ Wagner H, Breu W, Willer F, Wierer M, Remiger P, Schwenker G. In vitro inhibition of arachidonate metabolism by some alkamides and prenylated phenols. Planta Med 1989; 55: 566- 7 .

${ }^{125}$ Feisst C, Albert D, Verotta L, Werz O. Evaluation of hyperforin analogues for inhibition of 5-lipoxygenase. Med Chem 2005; 1: 287-91.

${ }^{126}$ Feisst C, Franke L, Appendino G, Werz O. Identification of molecular targets of the oligomeric nonprenylated acylphloroglucinols from Myrtus communis and their implication as anti-inflammatory compounds. J Pharmacol Exp Ther 2005; 315: 389-96.

127 Sud'ina GF, Mirzoeva OK, Pushkareva MA, Korshunova GA, Sumbatyan NV, Varfolomeev SD. Caffeic acid phenethyl ester as a lipoxygenase inhibitor with antioxidant properties. FEBS Lett 1993; 329: 21 - 4.

${ }^{128}$ Du L, Zhang Z, Luo X, Chen K, Shen X, Jiang H. Binding investigation of human 5-lipoxygenase with its inhibitors by SPR technology correlating with molecular docking simulation. J Biochem (Tokyo) 2006; 139: $715-23$.

${ }^{129}$ Ammon HP, Anazodo MI, Safayhi H, Dhawan BN, Srimal RC. Curcumin: a potent inhibitor of leukotriene B4 formation in rat peritoneal polymorphonuclear neutrophils (PMNL). Planta Med 1992; 58: 226.

130 Njamen D, Talla E, Mbafor JT, Fomum ZT, Kamanyi A, Mbanya JC et al. Anti-inflammatory activity of erycristagallin, a pterocarpene from Erythrina mildbraedii. Eur J Pharmacol 2003; 468: 67- 74.

${ }^{131}$ Kimura Y, Okuda H, Kubo M. Effects of stilbenes isolated from medicinal plants on arachidonate metabolism and degranulation in human polymorphonuclear leukocytes. J Ethnopharmacol 1995; 45: 131-9.

${ }^{132}$ Egan D, O'Kennedy R, Moran E, Cox D, Prosser E, Thornes RD. The pharmacology, metabolism, analysis, and applications of coumarin and coumarin-related compounds. Drug Metab Rev 1990; 22: 503 29.

133 Hoult JR, Paya M. Pharmacological and biochemical actions of simple coumarins: natural products with therapeutic potential. Gen Pharmacol 1996; 27: 713-22.

${ }^{134}$ Fylaktakidou KC, Hadjipavlou-Litina DJ, Litinas KE, Nicolaides DN. Natural and synthetic coumarin derivatives with anti-inflammatory/ antioxidant activities. Curr Pharm Des 2004; 10: 3813 - 33.

${ }^{135}$ Kimura Y, Okuda H, Arichi S, Baba K, Kozawa M. Inhibition of the formation of 5-hydroxy-6,8,11,14-eicosatetraenoic acid from arachidonic acid in polymorphonuclear leukocytes by various coumarins. Biochim Biophys Acta 1985; 834: 224 -9.

${ }^{136}$ Hoult JR, Forder RA, de las Heras B, Lobo IB, Paya M. Inhibitory activity of a series of coumarins on leukocyte eicosanoid generation. Agents Actions $1994 ; 42: 44-9$.

137 Wagner H, Fessler B. In vitro 5-lipoxygenase inhibition by Eclipta alba extracts and the coumestan derivative wedelolactone. Planta Med 1986; 52: $374-7$.

${ }^{138}$ Hiermann A, Schantl D. Antiphlogistic and antipyretic activity of Peucedanum ostruthium. Planta Med 1998; 64: 400-3.

${ }^{139}$ Abad MJ, de las Heras B, Silvan AM, Pascual R, Bermejo P, Rodriquez B et al. Effects of furocoumarins from Cachrys trifida on some macrophage functions. J Pharm Pharmacol 2001; 53: 1163-8.

140 Ohkawa S, Terao T, Murakami M, Matsumoto T, Goto G. Reduction of 2,3,5-trimethyl-6-(3-pyridylmethyl)-1,4-benzoquinone by PB-3c cells and biological activity of its hydroquinone. Chem Pharm Bull (Tokyo) 1991; 39: 917-21.

141 Reddanna P, Rao MK, Reddy CC. Inhibition of 5-lipoxygenase by vitamin E. FEBS Lett 1985; 193: 39-43.
${ }^{142}$ Fukuyama Y, Kiriyama Y, Okino J, Kodama M, Iwaki H, Hosozawa S et al. Naturally occurring 5-lipoxygenase inhibitor. II. Structures and syntheses of ardisianones $A$ and $B$, and maesanin, alkenyl-1,4-benzoquinones from the rhizome of Ardisia japonica. Chem Pharm Bull (Tokyo) 1993; 41: $561-5$.

${ }^{143}$ Abourashed EA, Muhammad I, Resch M, Bauer R, el-Feraly FS, Hufford CD. Inhibitory effects of maesanin and analogs on arachidonic acid metabolizing enzymes. Planta Med 2001; 67: 360-1.

${ }^{144}$ Fukuyama Y, Kiriyama Y, Kodama M, Iwaki H, Hosozawa S, Aki S et al. Naturally occurring 5-lipoxygenase inhibitors. VI. Structures of ardisiaquinones D, E, and F from Ardisia sieboldii. Chem Pharm Bull (Tokyo) 1995; 43: $1391-4$.

145 Fukuyama Y, Kiriyama Y, Kodama M, Iwaki H, Hosozawa S, Aki S et al. Total synthesis of ardisiaquinone A, a potent 5-lipoxygenase inhibitor, isolated from Ardisia sieboldii, and degree of 5-lipoxygenase inhibitory activity of its derivatives. Chem Pharm Bull (Tokyo) 1994; 42: $2211-3$.

${ }^{146}$ Fukuishi N, Takada T, Fukuyama Y, Akagi M. Antiallergic effect of ardisiaquinone $\mathrm{A}$, a potent 5-lipoxygenase inhibitor. Phytomedicine 2001; 8: 460-4.

147 Tziveleka LA, Abatis D, Paulus K, Bauer R, Vagias C, Roussis V. Marine polyprenylated hydroquinones, quinones, and chromenols with inhibitory effects on leukotriene formation. Chem Biodivers 2005; 2: $901-9$.

${ }^{148}$ Houghton PJ, Zarka R, de las Heras B, Hoult JR. Fixed oil of Nigella sativa and derived thymoquinone inhibit eicosanoid generation in leukocytes and membrane lipid peroxidation. Planta Med 1995; 61: $33-6$.

${ }^{149}$ El-Dakhakhny M, Madi NJ, Lembert N, Ammon HP. Nigella sativa oil, nigellone and derived thymoquinone inhibit synthesis of 5-lipoxygenase products in polymorphonuclear leukocytes from rats. J Ethnopharmacol 2002; 81: $161-4$.

150 Benrezzouk R, Terencio MC, Ferrandiz ML, Hernandez-Perez M, Rabanal R, Alcaraz MJ. Inhibition of 5-lipoxygenase activity by the natural anti-inflammatory compound aethiopinone. Inflamm Res 2001; 50: 96-101.

151 Matsui N, Fukuishi N, Fukuyama Y, Yasui Y, Akagi M. Protective effect of the 5-lipoxygenase inhibitor ardisiaquinone $\mathrm{A}$ on hepatic ischemia-reperfusion injury in rats. Planta Med 2005; 71: 717-20.

152 Safayhi H, Sailer ER. Anti-inflammatory actions of pentacyclic triterpenes. Planta Med 1997; 63: 487-93.

153 Ammon HP. Boswellic acids in chronic inflammatory diseases. Planta Med 2006; 72: 1100-16.

${ }^{154}$ Safayhi H, Sailer ER, Ammon HP. Mechanism of 5-lipoxygenase inhibition by acetyl-11-keto-beta-boswellic acid. Mol Pharmacol 1995; 47: $1212-6$.

155 Sailer ER, Schweizer S, Boden SE, Ammon HP, Safayhi H. Characterization of an acetyl-11-keto-beta-boswellic acid and arachidonate-binding regulatory site of 5 -lipoxygenase using photoaffinity labeling. Eur J Biochem 1998; 256: 364-8.

156 Poeckel D, Werz O. Boswellic acids: Pharmacological actions and molecular targets. Curr Med Chem 2006; 28: 3359-69.

157 Altmann A, Poeckel D, Fischer L, Schubert-Zsilavecz M, Steinhilber D, Werz O. Coupling of boswellic acid-induced $\mathrm{Ca} 2+$ mobilisation and MAPK activation to lipid metabolism and peroxide formation in human leucocytes. Br J Pharmacol 2004; 141: 223 - 32.

158 Safayhi H, Mack T, Sabieraj J, Anazodo MI, Subramanian LR, Ammon HP. Boswellic acids: novel, specific, nonredox inhibitors of 5-lipoxygenase. J Pharmacol Exp Ther 1992; 261: 1143-6.

159 Werz O, Schneider N, Brungs M, Sailer ER, Safayhi H, Ammon HPT et al. A test system for leukotriene synthesis inhibitors based on the invitro differentiation of the human leukemic cell lines HL-60 and Mono Mac 6. Naunyn Schmiedebergs Arch Pharmacol 1997; 356: $441-5$.

160 Boden SE, Schweizer S, Bertsche T, Dufer M, Drews G, Safayhi H. Stimulation of leukotriene synthesis in intact polymorphonuclear cells by the 5-lipoxygenase inhibitor 3-oxo-tirucallic acid. Mol Pharmacol 2001; 60: $267-73$.

${ }^{161}$ Moon TC, Lin CX, Lee JS, Kim DS, Bae K, Son KH et al. Anti-inflammatory activity of astilbic acid from Astilbe chinensis. Biol Pharm Bull 2005; $28: 24-6$.

162 Giner-Larza EM, Manez S, Giner RM, Recio MC, Prieto JM, Cerda-Nicolas $\mathrm{M}$ et al. Anti-inflammatory triterpenes from Pistacia terebinthus galls. Planta Med 2002; 68: $311-5$. 
163 Giner-Larza EM, Manez S, Recio MC, Giner RM, Prieto JM, Cerda-Nicolas $\mathrm{M}$ et al. Oleanonic acid, a 3-oxotriterpene from Pistacia, inhibits leukotriene synthesis and has anti-inflammatory activity. Eur J Pharmacol 2001; 428: 137-43.

164 Diaz AM, Abad MJ, Fernandez L, Recuero C, Villaescusa L, Silvan AM et al. In vitro anti-inflammatory activity of iridoids and triterpenoid compounds isolated from Phillyrea latifolia L. Biol Pharm Bull 2000; 23: $1307-13$

165 Ulusu NN, Ercil D, Sakar MK, Tezcan EF. Abietic acid inhibits lipoxygenase activity. Phytother Res 2002; 16: 88 -90.

166 Sailer ER, Subramanian LR, Rall B, Hoernlein RF, Ammon HP, Safayhi H. Acetyl-11-keto-beta-boswellic acid (AKBA): structure requirements for binding and 5-lipoxygenase inhibitory activity. $\mathrm{Br} \mathrm{J}$ Pharmacol 1996; 117: 615-8.

167 Poeckel D, Tausch L, Kather N, Jauch J, Werz O. Boswellic acids stimulate arachidonic acid release and 12-lipoxygenase activity in human platelets independent of $\mathrm{Ca} 2+$ and differentially interact with platelet-type 12-lipoxygenase. Mol Pharmacol 2006; 70: 1071 -8.

168 Poeckel D, Tausch L, George S, Jauch J, Werz 0. 3-O-Acetyl-11-ketoboswellic acid decreases basal intracellular Ca2+ levels and inhibits agonist-induced $\mathrm{Ca}^{2+}$ mobilization and mitogen-activated protein kinase activation in human monocytic cells. J Pharmacol Exp Ther 2006; 316: 224-32.

169 Poeckel D, Tausch L, Altmann A, Feisst C, Klinkhardt U, Graff J et al. Induction of central signalling pathways and select functional effects in human platelets by beta-boswellic acid. Br J Pharmacol 2005; 146: 514-24.

170 Merfort I. Arnica: new insights on the molecular mode of action of a traditional medicinal plant. Forsch Komplementarmed Klass Naturheilkd 2003; 10 Suppl 1: $45-8$.

171 Zhang S, Won YK, Ong CN, Shen HM. Anti-cancer potential of sesquiterpene lactones: bioactivity and molecular mechanisms. Curr Med Chem Anticancer Agents 2005; 5: 239-49.

172 Rekka EA, Kourounakis AP, Kourounakis PN. Investigation of the effect of chamazulene on lipid peroxidation and free radical processes. Res Commun Mol Pathol Pharmacol 1996; 92: 361 - 4.

173 Safayhi H, Sabieraj J, Sailer ER, Ammon HP. Chamazulene: an antioxidant-type inhibitor of leukotriene B4 formation. Planta Med 1994; 60: $410-3$

174 Abe M, Ozawa Y, Uda Y, Morimitsu Y, Nakamura Y, Osawa T. A novel labdane-type trialdehyde from myoga (Zingiber mioga Roscoe) that potently inhibits human platelet aggregation and human 5-lipoxygenase. Biosci Biotechnol Biochem 2006; 70: 2494-500.

175 Feisst C, Albert D, Steinhilber D, Werz O. The aminosteroid phospholipase $C$ antagonist U-73122 (1-[6-[[17-beta-3-methoxyestra-1,3,5 (10)-trien-17-yl lamino|hexyl]-1H-pyrro le-2,5-dione) potently inhibits human 5-lipoxygenase in vivo and in vitro. Mol Pharmacol 2005; 67: $1751-7$.

176 Sumner H, Salan U, Knight DW, Hoult JR. Inhibition of 5-lipoxygenase and cyclo-oxygenase in leukocytes by feverfew. Involvement of sesquiterpene lactones and other components. Biochem Pharmacol 1992; 43: 2313-20.

177 Liao YH, Houghton PJ, Hoult JR. Novel and known constituents from Buddleja species and their activity against leukocyte eicosanoid generation. J Nat Prod 1999; 62: 1241 - 5.

${ }^{178}$ Ben-Chetrit E, Levy M. Colchicine: 1998 update. Semin Arthritis Rheum 1998; 28: $48-59$.

179 Reibman J, Haines KA, Rich AM, Cristello P, Giedd KN, Weissmann G. Colchicine inhibits ionophore-induced formation of leukotriene B4 by human neutrophils: the role of microtubules. J Immunol 1986; 136: $1027-32$.

180 Peters-Golden M, McNish RW, Davis JA, Blackwood RA, Brock TG. Colchicine inhibits arachidonate release and 5-lipoxygenase action in alveolar macrophages. Am J Physiol 1996; 271: L1004-13.

181 Vavreckova C, Gawlik I, Muller K. Benzophenanthridine alkaloids of Chelidonium majus; I. Inhibition of 5- and 12-lipoxygenase by a nonredox mechanism. Planta Med 1996; 62: 397-401.

182 Choi YH, Shin EM, Kim YS, Cai XF, Lee JJ, Kim HP. Anti-inflammatory principles from the fruits of Evodia rutaecarpa and their cellular action mechanisms. Arch Pharm Res 2006; 29: 293 - 7.

${ }^{183}$ Adams M, Kunert O, Haslinger E, Bauer R. Inhibition of leukotriene biosynthesis by quinolone alkaloids from the fruits of Evodia rutaecarpa. Planta Med 2004; 70: $904-8$.
${ }^{184}$ Danz H, Stoyanova S, Thomet OA, Simon HU, Dannhardt G, Ulbrich H et al. Inhibitory activity of tryptanthrin on prostaglandin and leukotriene synthesis. Planta Med 2002; 68: 875-80.

185 Molina P, Tarraga A, Gonzalez-Tejero A, Rioja I, Ubeda A, Terencio MC et al. Inhibition of leukocyte functions by the alkaloid isaindigotone from Isatis indigotica and some new synthetic derivatives. J Nat Prod 2001; 64: 1297 - 300 .

${ }^{186}$ Micallef MJ, Iwaki K, Ishihara T, Ushio S, Aga M, Kunikata T et al. The natural plant product tryptanthrin ameliorates dextran sodium sulfate-induced colitis in mice. Int Immunopharmacol 2002; 2: 565 - 78 .

187 Recio MC, Cerda-Nicolas M, Potterat O, Hamburger M, Rios JL. Antiinflammatory and antiallergic activity in vivo of lipophilic Isatis tinctoria extracts and tryptanthrin. Planta Med 2006; 72: 539-46.

188 Salari H, Braquet P, Borgeat P. Comparative effects of indomethacin, acetylenic acids, 15-HETE, nordihydroguaiaretic acid and BW755C on the metabolism of arachidonic acid in human leukocytes and platelets. Prostaglandins Leukot Med 1984; 13: 53-60.

${ }^{189}$ Vanderhoek JY, Bryant RW, Bailey JM. Inhibition of leukotriene biosynthesis by the leukocyte product 15 -hydroxy-5,8,11,13-eicosatetraenoic acid. J Biol Chem 1980; 255: $10064-6$

190 Vanderhoek JY, Bryant RW, Bailey JM. Regulation of leukocyte and platelet lipoxygenases by hydroxyeicosanoids. Biochem Pharmacol 1982; 31: 3463-7.

191 Arai Y, Shimoji K, Konno M, Konishi Y, Okuyama S, Iguchi S et al. Synthesis and 5-lipoxygenase inhibitory activities of eicosanoid compounds. J Med Chem 1983; 26: 72 -8.

192 Koshishara Y, Murota S, Petasis NA, Nicolaou KC. Selective inhibition of 5-lipoxygenase by 5,6-methanoleukotriene A4, a stable analogue of leukotriene A4. FEBS Lett 1982; 143: $13-6$.

${ }^{193}$ Croft KD, Beilin LJ, Ford GL. Differential inhibition of thromboxane B2 and leukotriene B4 biosynthesis by two naturally occurring acetylenic fatty acids. Biochim Biophys Acta 1987; 921: 621 - 4 .

194 Redl K, Breu W, Davis B, Bauer R. Anti-inflammatory active polyacetylenes from Bidens campylotheca. Planta Med 1994; 60: 58 - 62.

195 Kraus CM, Neszmelyi A, Holly S, Wiedemann B, Nenninger A, Torssell $\mathrm{KB}$ et al. New acetylenes isolated from the bark of Heisteria acuminata. J Nat Prod 1998; 61: $422-7$.

${ }^{196}$ Alanko J, Kurahashi Y, Yoshimoto , Yamamoto S, Baba K. Panaxynol, a polyacetylene compound isolated from oriental medicines, inhibits mammalian lipoxygenases. Biochem Pharmacol 1994; 48: 1979-81.

197 Wagner H, Dorsch W, Bayer T, Breu W, Willer F. Antiasthmatic effects of onions: inhibition of 5-lipoxygenase and cyclooxygenase in vitro by thiosulfinates and "Cepaenes". Prostaglandins Leukot Essent Fatty Acids 1990; 39: 59-62.

198 Sendl A, Elbl G, Steinke B, Redl K, Breu W, Wagner H. Comparative pharmacological investigations of Allium ursinum and Allium sativum. Planta Med 1992; 58: 1 - 7 .

${ }^{199}$ Xiao H, Parkin KL. Antioxidant functions of selected allium thiosulfinates and S-alk(en)yl-L-cysteine sulfoxides. J Agric Food Chem 2002; 50: $2488-93$.

${ }^{200}$ Dorsch W, Wagner H, Bayer T, Fessler B, Hein G, Ring J et al. Anti-asthmatic effects of onions. Alk(en)ylsulfinothioic acid alk(en)yl-esters inhibit histamine release, leukotriene and thromboxane biosynthesis in vitro and counteract PAF and allergen-induced bronchial obstruction in vivo. Biochem Pharmacol 1988; 37: 4479-86.

${ }^{201}$ Schwaiger S, Adams M, Seger C, Ellmerer EP, Bauer R, Stuppner H. New constituents of Leontopodium alpinum and their in vitro leukotriene biosynthesis inhibitory activity. Planta Med 2004; 70: 978 - 85

202 Rollinger JM, Langer T, Stuppner H. Strategies for efficient lead structure discovery from natural products. Curr Med Chem 2006; 13 : $1491-507$

${ }^{203}$ Franke L, Schwarz O, Muller-Kuhrt L, Hoernig C, Fischer L, George S et al. Identification of natural-product-derived inhibitors of 5-lipoxygenase activity by ligand-based virtual screening. J Med Chem 2007; 50: $2640-6$.

${ }^{204}$ Chwalek M, Lalun N, Bobichon H, Ple K, Voutquenne-Nazabadioko L. Structure-activity relationships of some hederagenin diglycosides: haemolysis, cytotoxicity and apoptosis induction. Biochim Biophys Acta 2006; 1760: $1418-27$.

${ }^{205}$ Morris AJ, Frohman MA, Engebrecht J. Measurement of phospholipase D activity. Anal Biochem 1997; 252: 1 -9.

${ }^{206}$ Kondo T, Beutler E. Depletion of red cell ATP by incubation with 2deoxyglucose. J Lab Clin Med 1979; 94: 617-23. 
${ }^{207}$ Frankel EN. The antioxidant and nutritional effects of tocopherols, ascorbic acid and beta-carotene in relation to processing of edible oils. Bibl Nutr Dieta; 1989: 297-312.

208 Orning L, Krivi G, Fitzpatrick FA. Leukotriene A4 hydrolase. Inhibition by bestatin and intrinsic aminopeptidase activity establish its functional resemblance to metallohydrolase enzymes. J Biol Chem 1991; 266: $1375-8$.

${ }^{209}$ Chang J, Skowronek MD, Cherney ML, Lewis AJ. Differential effects of putative lipoxygenase inhibitors on arachidonic acid metabolism in cell-free and intact cell preparations. Inflammation 1984; 8: 143-55.

${ }^{210}$ Bucar F, Resch M, Bauer R, Burits M, Knauder E, Schubert-Zsilavecz M. 5-Methylflavasperone and rhamnetin from Guiera senegalensis and their antioxidative and 5-lipoxygenase inhibitory activity. Pharmazie 1998; 53: 875-8.

211 Skaltsa H, Bermejo P, Lazari D, Silvan AM, Skaltsounis AL, Sanz A et al. Inhibition of prostaglandin E2 and leukotriene C4 in mouse peritoneal macrophages and thromboxane B2 production in human platelets by flavonoids from Stachys chrysantha and Stachys candida. Biol Pharm Bull 2000; 23: 47-53.

212 Kimura Y, Okuda H, Arichi S. Studies on Scutellariae Radix; XIII1. Effects of various flavonoids on arachidonate Metabolismmin leukocytes. Planta Med 1985; 51: $132-6$.

213 Dehmlow C, Murawski N, de Groot H. Scavenging of reactive oxygen species and inhibition of arachidonic acid metabolism by silibinin in human cells. Life Sci 1996; 58: $1591-600$.

214 Son MJ, Moon TC, Lee EK, Son KH, Kim HP, Kang SS et al. Naturally occurring biflavonoid, ochnaflavone, inhibits cyclooxygenases-2 and 5lipoxygenase in mouse bone marrow-derived mast cells. Arch Pharm Res 2006; 29: $282-6$.

${ }^{215}$ Hartisch C, Kolodziej H, von Bruchhausen F. Dual inhibitory activities of tannins from Hamamelis virginiana and related polyphenols on 5lipoxygenase and lyso-PAF: acetyl-CoA acetyltransferase. Planta Med 1997; 63: $106-10$.

${ }^{216}$ Hong J, Smith TJ, Ho CT, August DA, Yang CS. Effects of purified green and black tea polyphenols on cyclooxygenase- and lipoxygenase-dependent metabolism of arachidonic acid in human colon mucosa and colon tumor tissues. Biochem Pharmacol 2001; 62: 1175-83.
217 Petroni A, Blasevich M, Papini N, Salami M, Sala A, Galli C. Inhibition of leukocyte leukotriene B4 production by an olive oil-derived phenol identified by mass-spectrometry. Thromb Res 1997; 87: 315-22.

218 Dohi T, Anamura S, Shirakawa M, Okamoto H, Tsujimoto A. Inhibition of lipoxygenase by phenolic compounds. Jpn J Pharmacol 1991; 55: $547-50$.

${ }^{219}$ Zschocke S, Lehner M, Bauer R. 5-Lipoxygenase and cyclooxygenase inhibitory active constituents from Qianghuo (Notopterygium incisum). Planta Med 1997; 63: 203-6.

${ }^{220}$ Kimura Y, Okuda H, Okuda T, Hatano T, Arichi S. Studies on the activities of tannins and related compounds, X. Effects of caffeetannins and related compounds on arachidonate metabolism in human polymorphonuclear leukocytes. J Nat Prod 1987; 50: 392 -9.

${ }^{221}$ Wang JP, Ho TF, Chang LC, Chen CC. Anti-inflammatory effect of magnolol, isolated from Magnolia officinalis, on A23187-induced pleurisy in mice. J Pharm Pharmacol 1995; 47: 857 - 60.

222 Wang JP, Hsu MF, Raung SL, Chen CC, Kuo JS, Teng CM. Anti-inflammatory and analgesic effects of magnolol. Naunyn Schmiedebergs Arch Pharmacol 1992; 346: 707-12.

${ }^{223}$ Hsu MF, Lu MC, Tsao LT, Kuan YH, Chen CC, Wang JP. Mechanisms of the influence of magnolol on eicosanoid metabolism in neutrophils. Biochem Pharmacol 2004; 67: 831-40.

${ }^{224}$ Gissurarson SR, Sigurdsson SB, Wagner H, Ingolfsdottir K. Effect of lobaric acid on cysteinyl-leukotriene formation and contractile activity of guinea pig taenia coli. J Pharmacol Exp Ther 1997; 280: 770 -3.

225 Gongora L, Giner RM, Manez S, Recio Mdel C, Schinella G, Rios JL. Effects of caffeoyl conjugates of isoprenyl-hydroquinone glucoside and quinic acid on leukocyte function. Life Sci 2002; 71: 2995-3004.

${ }^{226}$ Adams M, Pacher T, Greger H, Bauer R. Inhibition of leukotriene biosynthesis by stilbenoids from Stemona species. J Nat Prod 2005; 68: $83-5$.

227 de las Heras B, Abad MJ, Silvan AM, Pascual R, Bermejo P, Rodriguez B et al. Effects of six diterpenes on macrophage eicosanoid biosynthesis. Life Sci 2001; 70: 269-78. 